Prepared in cooperation with the Federal Emergency Management Agency

\title{
Floods of June 2012 in Northeastern Minnesota
}

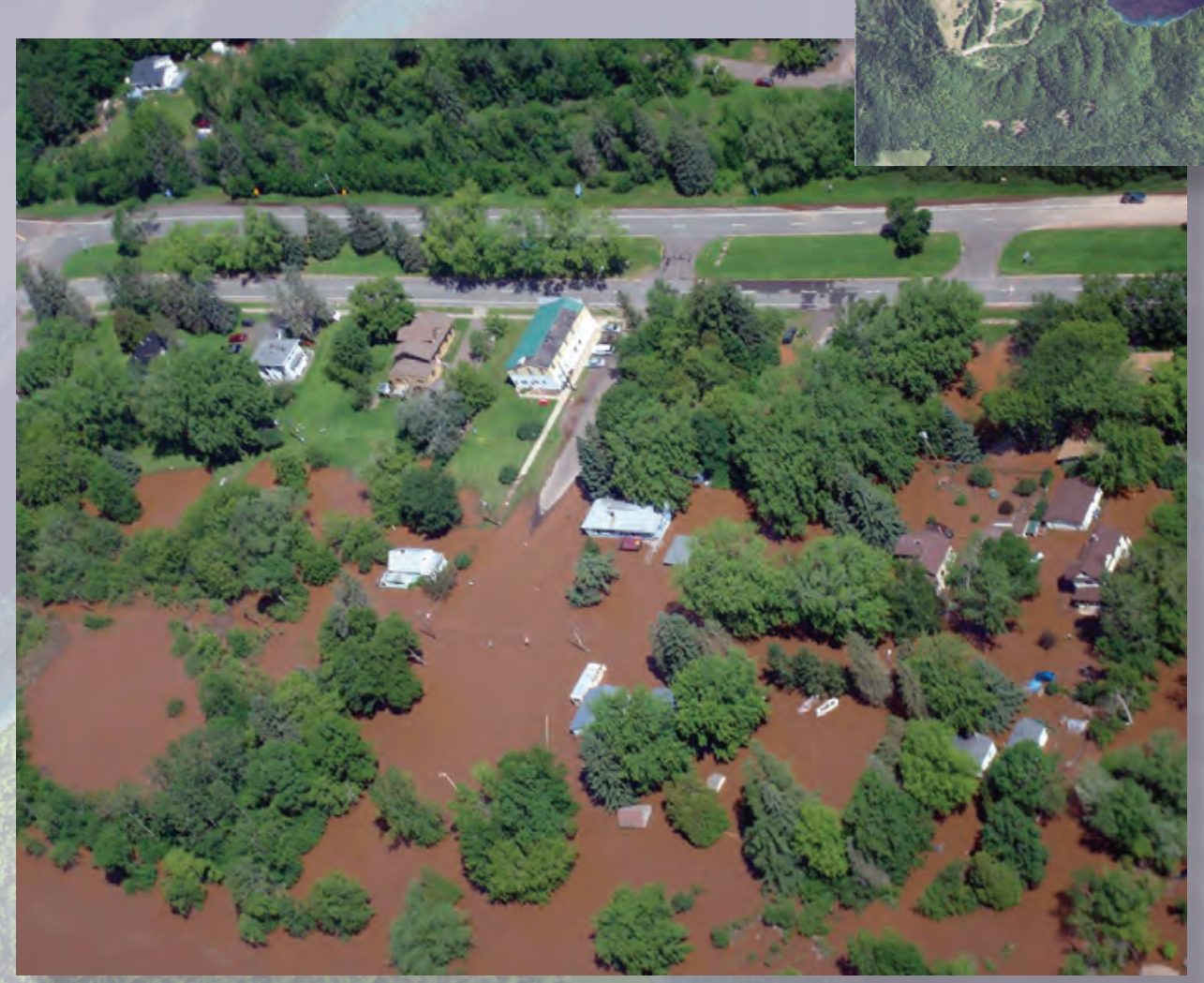

Scientific Investigations Report 2012-5283 
Cover. Left: View of homes flooded by the St. Louis River in the Fond du Lac neighborhood of Duluth, Minnesota, taken from a helicopter on June 21, 2012 (photograph provided by Walter Leu, Minnesota Department of Transportation).

Top right: An inundation map showing approximate flood-peak extents and depths for June 2012 for the St. Louis River at the Fond du Lac neighborhood of Duluth, Minnesota (entire map is in appendix 2 of the report). Map prepared by Christiana Czuba, U.S. Geological Survey, November 2012. Map base from 2010 National Agricultural Imagery program (U.S. Department of Agriculture, 2010). 


\section{Floods of June 2012 in Northeastern Minnesota}

By Christiana R. Czuba, James D. Fallon, and Erich W. Kessler

Prepared in cooperation with the Federal Emergency Management Agency

Scientific Investigations Report 2012-5283 


\title{
U.S. Department of the Interior \\ KEN SALAZAR, Secretary \\ U.S. Geological Survey \\ Marcia K. McNutt, Director
}

\author{
U.S. Geological Survey, Reston, Virginia: 2012
}

For more information on the USGS - the Federal source for science about the Earth, its natural and living resources, natural hazards, and the environment, visit http://www.usgs.gov or call 1-888-ASK-USGS.

For an overview of USGS information products, including maps, imagery, and publications, visit http://www.usgs.gov/pubprod

To order this and other USGS information products, visit http://store.usgs.gov

Any use of trade, firm, or product names is for descriptive purposes only and does not imply endorsement by the U.S. Government.

Although this information product, for the most part, is in the public domain, it also may contain copyrighted materials as noted in the text. Permission to reproduce copyrighted items must be secured from the copyright owner.

Suggested citation:

Czuba, C.R., Fallon, J.D., and Kessler, E.W., 2012, Floods of June 2012 in northeastern Minnesota: U.S. Geological Survey Scientific Investigations Report 2012-5283, 42 p. with 3 app. 


\section{Contents}

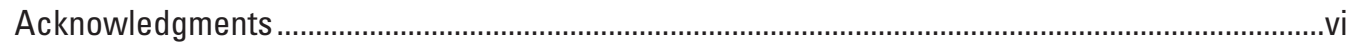

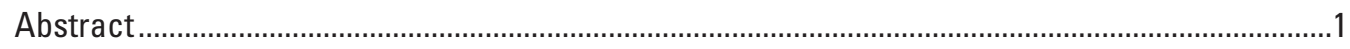

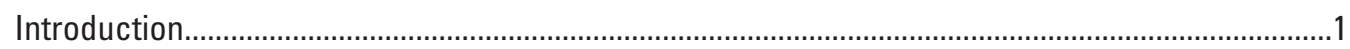

Purpose and Scope ......................................................................................................

Conditions Leading to the 2012 Floods in Northeastern Minnesota.........................................

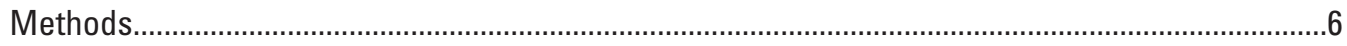

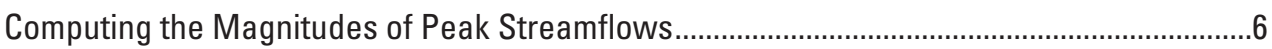

Estimating Annual Exceedance Probabilities of Peak Streamflows ......................................... 6

Collection of High-Water-Mark Data ....................................................................................

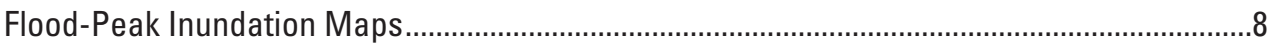

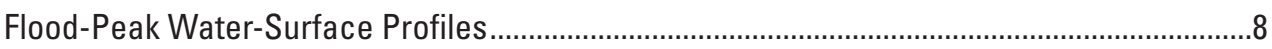

Floods of June 2012 in Northeastern Minnesota ...........................................................................9

Magnitudes and Estimated Annual Exceedance Probabilities of Peak Streamflows...............9

Flood-Peak Inundation Maps and Water-Surface Profiles ....................................................

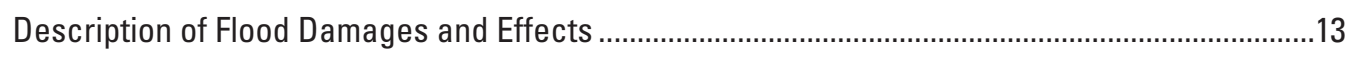

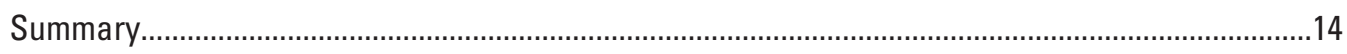

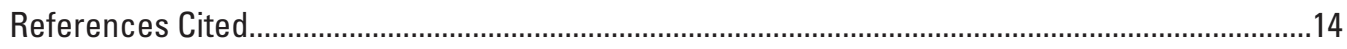

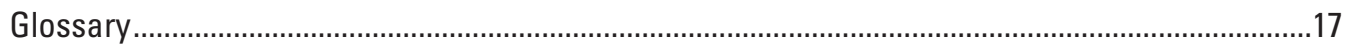

Appendix 1. High-Water-Mark Descriptions .........................................................................19

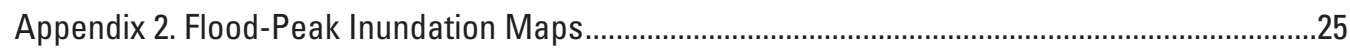

Appendix 3. Flood-Peak Water-Surface Profiles...........................................................................39

\section{Figures}

1. Map showing locations of study communities in the counties with disaster declarations in northeastern Minnesota affected by the June 19-20, 2012, flood events

2. Map showing distribution of 2-day rainfall totals for 7 a.m. Central Daylight Time June 19 through 7 a.m. Central Daylight Time June 21, 2012, and rainfall totals at selected National Weather Service Cooperative Observing - Fischer Porter precipitation stations

3. Graph showing cumulative daily rainfall during June 19-20, 2012, at selected National Weather Service Cooperative Observing - Fischer Porter precipitation stations in northeastern Minnesota ...

4. Map showing locations of selected U.S. Geological Survey streamgages in the counties with disaster declarations for the floods of June 2012 in northeastern Minnesota

5. Graph showing provisional stage hydrographs at selected U.S. Geological Survey streamgages in northeastern Minnesota for June 10 through July 29,2012 


\section{Tables}

1. Provisional total rainfall for June $19-20,2012$, at selected National Weather Service Cooperative Observing-Fischer Porter precipitation stations in northeastern Minnesota.

2. Provisional flood-peak gage heights, peak streamflows, and annual exceedance probabilities of peak streamflows during the floods of June 2012 at selected U.S. Geological Survey streamgages in northeastern Minnesota

\section{Appendix 1}

1-1. High-water-mark descriptions for the mapped communities of Barnum, Carlton, Duluth Heights neighborhood in Duluth, Fond du Lac neighborhood in Duluth, Moose Lake, and Thomson for the floods of June 2012 in northeastern Minnesota ......20

1-2. Descriptions of additional high-water marks for the floods of June 2012 in northeastern Minnesota....

\section{Appendix 2}

2-1. Map showing approximate extent and depth of flood-peak inundation, flood of June 2012, for the Moose Horn River at Barnum, Minnesota

2-2. Map showing approximate extent and depth of flood-peak inundation, flood of June 2012, for Otter Creek at Carlton, Minnesota

2-3. Map showing approximate extent and depth of flood-peak inundation, flood of June 2012, for Miller Creek at the Duluth Heights neighborhood, Duluth, Minnesota....30

2-4. Map showing approximate extent and depth of flood-peak inundation, flood of June 2012, for the St. Louis River at the Fond du Lac neighborhood, Duluth, Minnesota

2-5. Map showing approximate extent and depth of flood-peak inundation, flood of June 2012, for the Moose Horn River and Moosehead Lake at Moose Lake, Minnesota

2-6. Map showing approximate extent and depth of flood-peak inundation, flood of June 2012, for the Thomson Reservoir outflow near the St. Louis River at Thomson, Minnesota. 


\section{Appendix 3}

3-1. Graph showing flood-peak water-surface profile with selected high-water marks for the Moose Horn River at Barnum, Minnesota, for the flood of June 2012.

3-2. Graph showing flood-peak water-surface profile with selected high-water marks for Otter Creek at Carlton, Minnesota, for the flood of June 2012.

3-3. Graph showing flood-peak water-surface profile with selected high-water marks for Miller Creek at the Duluth Heights neighborhood, Duluth, Minnesota, for the flood of June 2012

3-4. Graph showing flood-peak water-surface profile with selected high-water marks for the St. Louis River at the Fond du Lac neighborhood, Duluth, Minnesota, for the flood of June 2012

3-5. Graph showing flood-peak water-surface profile with selected high-water marks for the Moose Horn River and Moosehead Lake at Moose Lake, Minnesota, for the flood of June 2012

3-6. Graph showing flood-peak water-surface profile with selected high-water marks for the Thomson Reservoir outflow near the St. Louis River at Thomson, Minnesota, for the flood of June 2012.

\section{Conversion Factors and Datums}

Inch/Pound to SI

\begin{tabular}{|c|c|c|}
\hline Multiply & By & To obtain \\
\hline \multicolumn{3}{|c|}{ Length } \\
\hline inch (in.) & 2.54 & centimeter $(\mathrm{cm})$ \\
\hline inch (in.) & 25.4 & millimeter (mm) \\
\hline foot $(\mathrm{ft})$ & 0.3048 & meter $(\mathrm{m})$ \\
\hline mile (mi) & 1.609 & kilometer (km) \\
\hline \multicolumn{3}{|c|}{ Area } \\
\hline square mile $\left(\mathrm{mi}^{2}\right)$ & 2.590 & square kilometer $\left(\mathrm{km}^{2}\right)$ \\
\hline \multicolumn{3}{|c|}{ Flow rate } \\
\hline cubic foot per second $\left(\mathrm{ft}^{3} / \mathrm{s}\right)$ & 0.02832 & cubic meter per second $\left(\mathrm{m}^{3} / \mathrm{s}\right)$ \\
\hline inch per hour (in/h) & 0.0254 & meter per hour (m/h) \\
\hline
\end{tabular}

Vertical coordinate information is referenced to the North American Vertical Datum of 1988 (NAVD 88) or the National Geodetic Vertical Datum of 1929 (NGVD 29).

Horizontal coordinate information is referenced to the North American Datum of 1983 (NAD 83).

Elevation, as used in this report, refers to distance above the vertical datum.

Water year is the 12-month period of October 1 through September 30 designated by the calendar year in which it ends. 


\section{Abbreviations}

$\begin{array}{ll}\text { AEP } & \text { annual exceedance probability } \\ \text { CDT } & \text { Central Daylight Time } \\ \text { CSG } & \text { crest-stage gage } \\ \text { DEM } & \text { digital elevation model } \\ \text { FEMA } & \text { Federal Emergency Management Agency } \\ \text { GIS } & \text { geographic information system } \\ \text { GPS } & \text { global positioning system } \\ \text { LiDAR } & \text { light detection and ranging } \\ \text { MDNR } & \text { Minnesota Department of Natural Resources } \\ \text { MDPS } & \text { Minnesota Department of Public Safety } \\ \text { MHSEM } & \text { Minnesota Homeland Security and Emergency Management } \\ \text { MnDOT } & \text { Minnesota Department of Transportation } \\ \text { NAVD 88 } & \text { North American Vertical Datum of 1988 } \\ \text { NGVD 29 } & \text { National Geodetic Vertical Datum of 1929 } \\ \text { NOAA } & \text { National Oceanic and Atmospheric Administration } \\ \text { NWS } & \text { National Weather Service } \\ \text { RTK-GPS } & \text { Real-Time Kinematic Global Positioning System } \\ \text { TIN } & \text { triangular irregular network } \\ \text { USACE } & \text { U.S. Geological Survey } \\ \text { USGS } & \text { WIE }\end{array}$

\section{Acknowledgments}

The authors would like to thank the National Weather Service, Minnesota Homeland Security and Emergency Management, and other member agencies of the Silver Jackets Hazard Mitigation Team for their coordination and assistance during the flood event and the course of this study. The city of Duluth and the U.S. Army Corps of Engineers Detroit District and St. Paul District are acknowledged for the collection of high-water-mark data that are included in this report.

U.S. Geological Survey staff who were instrumental in flood documentation for this study include Dan Daly, Erik Lahti, Greg Mitton, Brett Savage, Russ Buesing, Jeff Copa, John Greene, Josh Larson, Ben Otto, Eric Wakeman, John Kent, and Kristen Kieta. Chris Ellison and Moon Kim are thanked for critical reviews of this report. 


\title{
Floods of June 2012 in Northeastern Minnesota
}

\author{
By Christiana R. Czuba, James D. Fallon, and Erich W. Kessler
}

\section{Abstract}

During June 19-20, 2012, heavy rainfall, as much as 10 inches locally reported, caused severe flooding across northeastern Minnesota. The floods were exacerbated by wet antecedent conditions from a relatively rainy spring, with May 2012 as one of the wettest Mays on record in Duluth. The June 19-20, 2012, rainfall event set new records in Duluth, including greatest 2-day precipitation with 7.25 inches of rain. The heavy rains fell on three major watersheds: the Mississippi Headwaters; the St. Croix, which drains to the Mississippi River; and Western Lake Superior, which includes the St. Louis River and other tributaries to Lake Superior. Widespread flash and river flooding that resulted from the heavy rainfall caused evacuations of residents, and damages to residences, businesses, and infrastructure. In all, nine counties in northeastern Minnesota were declared Federal disaster areas as a result of the flooding.

Peak-of-record streamflows were recorded at 13 U.S. Geological Survey streamgages as a result of the heavy rainfall. Flood-peak gage heights, peak streamflows, and annual exceedance probabilities were tabulated for 35 U.S. Geological Survey streamgages. Flood-peak streamflows in June 2012 had annual exceedance probabilities estimated to be less than 0.002 ( 0.2 percent; recurrence interval greater than 500 years) for five streamgages, and between 0.002 and 0.01 ( 1 percent; recurrence interval greater than 100 years) for four streamgages. High-water marks were identified and tabulated for the most severely affected communities of Barnum (Moose Horn River), Carlton (Otter Creek), Duluth Heights neighborhood of Duluth (Miller Creek), Fond du Lac neighborhood of Duluth (St. Louis River), Moose Lake (Moose Horn River and Moosehead Lake), and Thomson (Thomson Reservoir outflow near the St. Louis River). Flood-peak inundation maps and water-surface profiles were produced for these six severely affected communities. The inundation maps were constructed in a geographic information system by combining high-water-mark data with high-resolution digital elevation model data. The flood maps and profiles show the extent and depth of flooding through the communities and can be used for flood response and recovery efforts by local, county, State, and Federal agencies.

\section{Introduction}

Flood information is needed by Federal, State, and local agencies to make informed decisions in meeting mission requirements related to flood hazard mitigation, planning, and response. For example, the Federal Emergency Management Agency (FEMA), U.S. Army Corps of Engineers (USACE), the National Weather Service (NWS) of the National Atmospheric and Oceanic Administration (NOAA), Minnesota Department of Natural Resources (MDNR), Minnesota Department of Public Safety (MDPS) and its division of Homeland Security and Emergency Management (MHSEM) need timely information on the magnitudes and frequency of floods to help respond to flood damage, enhance emergency response management, protect infrastructure, provide recovery guidance from the National Flood Insurance Program and State regulatory programs, and plan for future flood events.

In Minnesota, many of the agencies that need post-flood information are members of a State Hazard Mitigation Team commonly referred to as Silver Jackets. State Silver Jackets chapters are sponsored by the USACE and in Minnesota include as charter members, but is not limited to, the following agencies: USACE, FEMA, MDNR, MHSEM, NWS, and U.S. Geological Survey (USGS).

Heavy rains on June 19-20, 2012, caused severe flooding in northeastern Minnesota and prompted the NWS to issue areal flood, flash-flood, and river flood warnings. The flood peaks ${ }^{1}$ were exacerbated by a relatively rainy spring, including one of the wettest Mays on record (Minnesota Department of Natural Resources State Climatology Office, 2012a). During the flooding in June 2012, evacuations, water rescues, and road closures were common in communities affected by the flooding. Damages from flooding were extensive and included major transportation disruptions and damage to homes and businesses, dams and flood-control structures, and parks and recreation areas. Damage caused by the flooding resulted in a Presidential Disaster Declaration on July 6, 2012, for the nine counties in northeastern Minnesota affected by the June 19-20, 2012, flood events (Federal Emergency Management Agency, 2012; fig. 1). This disaster declaration also includes a separate storm event in central Minnesota on June 14, 2012, for six counties (Federal Emergency Management Agency, 2012; 


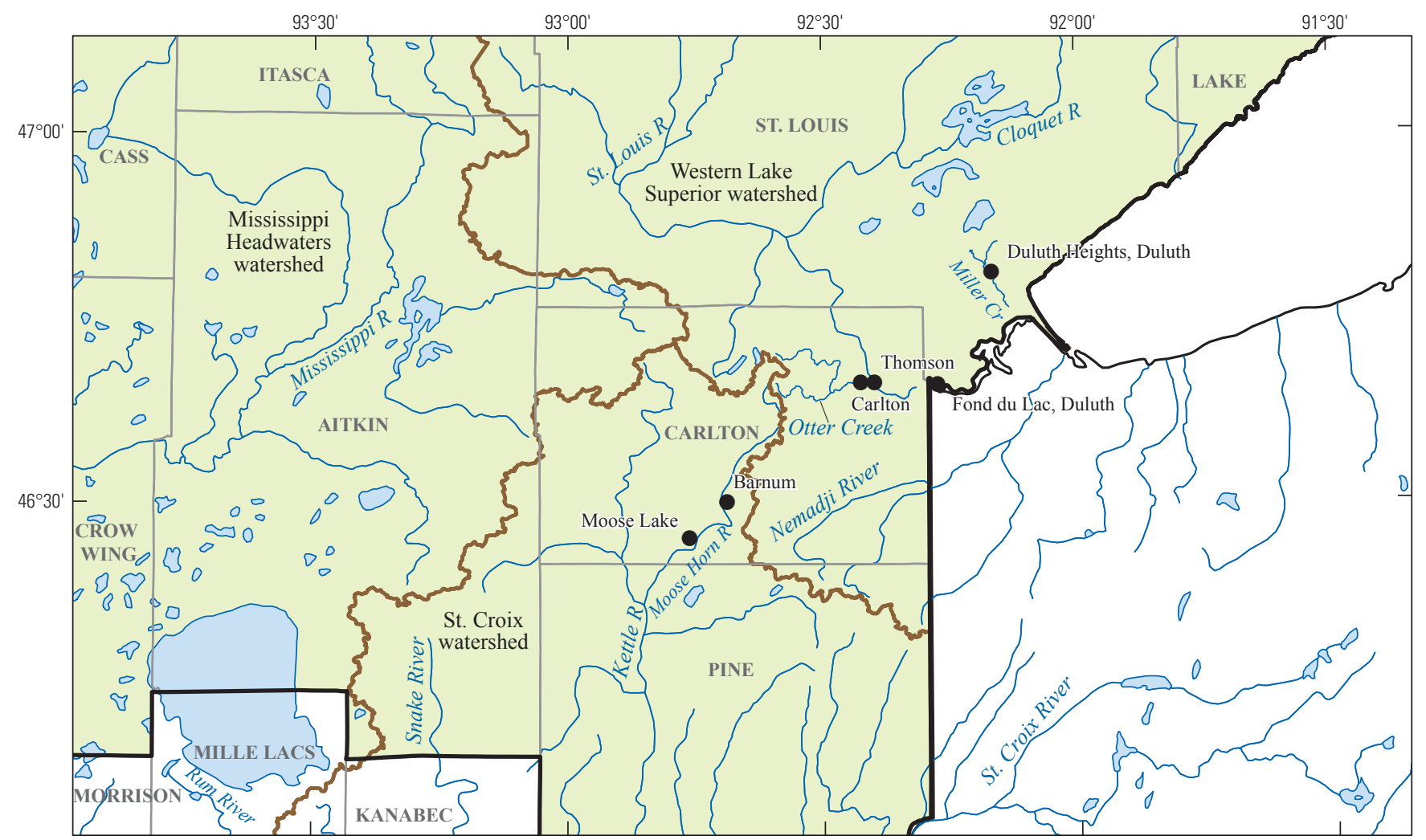

Base modified from Minnesota Department of Natural Resources, 1993, 1:24,000 and 1:100,000 and U.S. Geological Survey digital data, 1:200,000 Universal Transverse Mercator projection, Zone 15

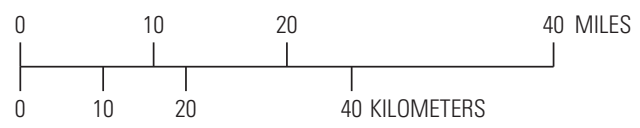

EXPLANATION
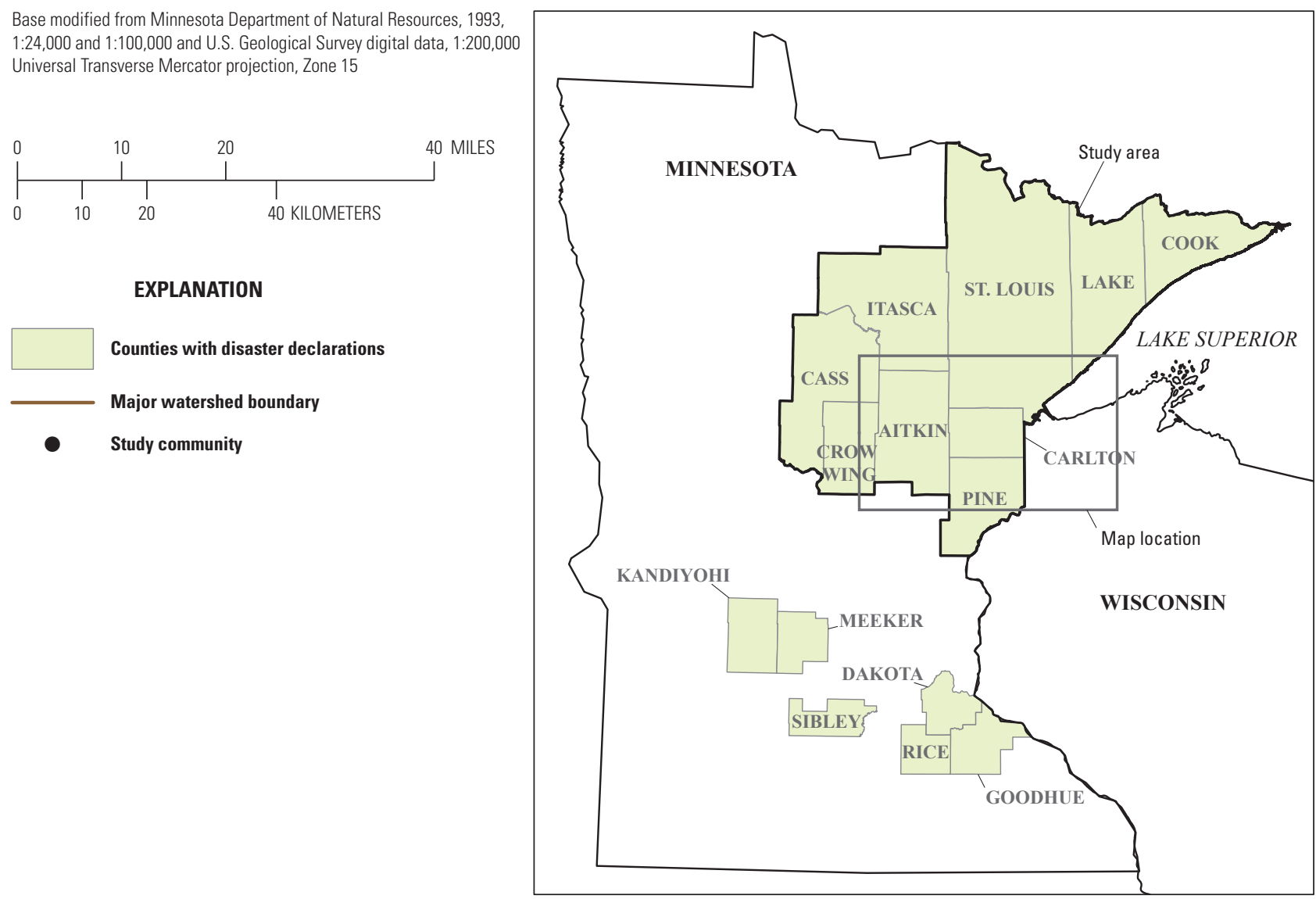

Figure 1. Locations of study communities in the counties with disaster declarations in northeastern Minnesota affected by the June 19-20, 2012, flood events. 
Minnesota Department of Natural Resources State Climatology Office, 2012b); however, this report focuses only on the flooding effects in northeastern Minnesota, including the nine contiguous counties of Aitkin, Carlton, Cass, Cook, Crow Wing, Itasca, Lake, Pine, and St. Louis (fig. 1).

Given the severity of the June 2012 flooding in northeastern Minnesota, the USGS, in cooperation with FEMA, lead a study to document the meteorological and hydrologic conditions leading to the flood, and compile flood-peak gage heights, streamflows, and annual exceedance probabilities at USGS streamgages. The study also provided data to construct flood profiles and flood-peak inundation maps. Flood profiles and flood-peak inundation maps were constructed for six communities in northeastern Minnesota (fig. 1): Barnum (Moose Horn River), Carlton (Otter Creek), Duluth Heights neighborhood of Duluth (Miller Creek), Fond du Lac neighborhood of Duluth (St. Louis River), Moose Lake (Moose Horn River and Moosehead Lake), and Thomson (Thomson Reservoir outflow near the St. Louis River). The USGS and FEMA collaborated and consulted with Silver Jackets team members extensively in determining locations needing flood documentation.

\section{Purpose and Scope}

The purpose of this report is to document the floods of June 2012 in northeastern Minnesota. This report documents the magnitude and extent of flooding and the methods used to define the extent of flooding. High-water-mark data were collected after the flood and used to develop flood-peak inundation maps for the six communities most affected by the riverine flooding: Barnum (Moose Horn River), Carlton (Otter Creek), Duluth Heights neighborhood of Duluth (Miller Creek), Fond du Lac neighborhood of Duluth (St. Louis River), Moose Lake (Moose Horn River and Moosehead Lake), and Thomson (Thomson Reservoir outflow near the St. Louis River). The report summarizes meteorological and hydrologic conditions leading up to the flood. The severity of flooding is put into regional context by computing flood-peak magnitudes and annual exceedance probabilities at 35 USGS streamgages in the counties in northeastern Minnesota with disaster declarations. Flood effects and damages are summarized on the basis of information obtained from FEMA, NWS, MDPS, MHSEM, MDNR, Minnesota Department of Transportation (MnDOT), local agencies, news accounts, photographs, and corroborated testimony from individuals in flood-affected communities.

\section{Conditions Leading to the 2012 Floods in Northeastern Minnesota}

The June 2012 flooding in northeastern Minnesota was caused by heavy rainfall on areas that had already received above-normal precipitation. For much of northeastern Minnesota, spring and early summer had the highest total rainfall levels as compared to historical data for the same months
(Minnesota Department of Natural Resources State Climatology Office, 2012c). May 2012 was one of the wettest Mays on record in some areas of central and northeastern Minnesota, and was the sixth wettest May on record for Duluth (Minnesota Department of Natural Resources State Climatology Office, 2012a).

In the weeks before the flooding rains of June 19-20, 2012, the ground was saturated from numerous storm systems that delivered 2-4 inches (in.) of rain across parts of northeastern Minnesota. On June 19, 2012, a warm front moved in and stalled across northern Minnesota, bringing waves of thunderstorms to the area (Graning and Hluchan, 2012). The heavy rainfall continued until late June 20, 2012, when a cold front moved through the area. Carlton County and southern St. Louis County had the highest levels of rainfall, and new records were set in Duluth, including greatest 2-day precipitation with 7.25 in. falling June 19-20, 2012 (Graning and Hluchan, 2012). Local reports of rainfall were as high as 8-10 in. throughout Duluth neighborhoods (Graning and Hluchan, 2012). This June 2012 flood event was the most damaging flood in Duluth's history, surpassing the August 1972 flood event (Minnesota Department of Natural Resources State Climatology Office, 2012d).

A spatial gridded dataset of estimated rainfall totals prepared by the NWS (National Weather Service, written commun., 2012) shows rainfall totals of 7 in. and greater for June 19-20, 2012, in parts of Carlton County and southern St. Louis County (fig. 2). Total rainfall amounts for six NWS Cooperative Observing-Fischer Porter precipitation stations in northeastern Minnesota recorded rainfall totals ranging from $2.73 \mathrm{in}$. at Eveleth in St. Louis County to 6.27 in. at Sandy Lake in Aitkin County for the storm event on June 19-20, 2012 (fig. 2; table 1). Local direct measurements of rainfall totals may differ from the spatial gridded dataset that is developed from radar data. A seventh Cooperative Observing - Fischer Porter precipitation station is located in Floodwood (not shown) in St. Louis County but was not included in this report because the gage was overtopped during the June rainfall and data were lost.

The cumulative 15-minute rainfall data from the six NWS Cooperative Observing-Fischer Porter precipitation stations (locations shown in fig. 2) indicate the magnitude and timing of the rain that fell throughout the storm events on June 19-20, 2012 (fig. 3). Instantaneous rainfall intensities were as great as 2 to 4 inches per hour (in/h) in the evening of June 19, 2012.

The heavy rains fell on three major watersheds: the Mississippi Headwaters; the St. Croix, which drains to the Mississippi River; and Western Lake Superior, which includes the St. Louis River and other tributaries to Lake Superior (fig. 2). Along the northern shore of Lake Superior, flash flooding was exacerbated by impervious soils and bedrock, and by the steep gradients of streams that drain directly to Lake Superior. In other areas receiving the heavy rainfall, storage from lakes and wetlands delayed and reduced the flood peaks but still resulted in record or near-record floods. 


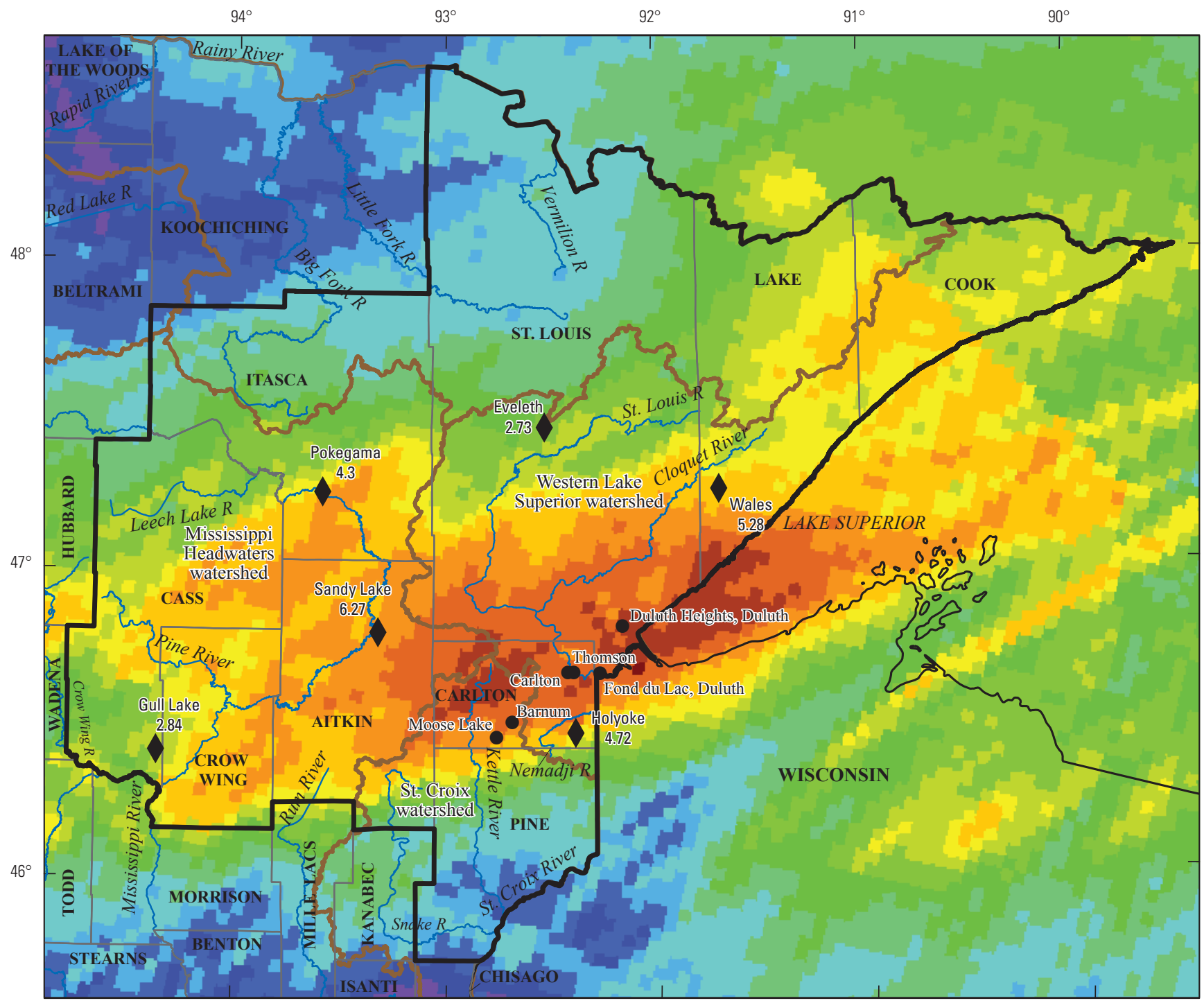

Base from Minnesota Department of Natural Resources, 1993, 1:24,000

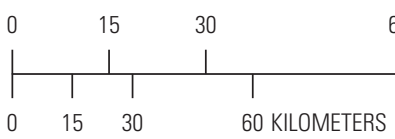

Universal Transverse Mercator projection, Zone 15

60 MILES

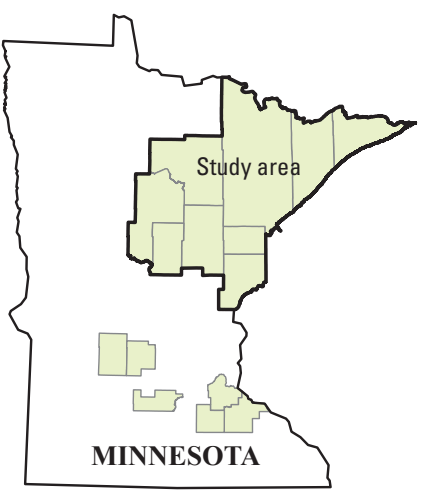

Radar-derived rainfall total-In inches

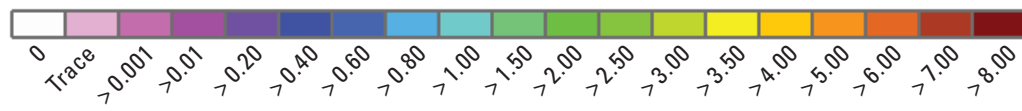

Figure 2. Distribution of 2-day rainfall totals for 7 a.m. Central Daylight Time June 19 through 7 a.m. Central Daylight Time June 21, 2012, and rainfall totals at selected National Weather Service (NWS) Cooperative Observing-Fischer Porter precipitation stations. Rainfall data provided by Steve Gohde and Diane Cooper of the National Weather Service (written commun., 2012). 
Table 1. Provisional total rainfall for June 19-20, 2012, at selected National Weather Service (NWS) Cooperative Observing-Fischer Porter precipitation stations in northeastern Minnesota.

[Total rainfall from Steve Gohde and Diane Cooper of the National Weather Service (written commun., 2012). Annual exceedance probabilities from Huff and Angel (1992)]

\begin{tabular}{lllllllll}
\hline $\begin{array}{c}\text { Precipitation } \\
\text { station name } \\
\text { (location } \\
\text { shown in } \\
\text { fig. 2) }\end{array}$ & County & $\begin{array}{c}\text { NWS } \\
\text { station } \\
\text { identifier }\end{array}$ & $\begin{array}{c}\text { Total } \\
\text { rainfall } \\
\text { (inches) }\end{array}$ & $\mathbf{0 . 2}$ & $\mathbf{0 . 1}$ & $\mathbf{0 . 0 4}$ & $\mathbf{0 . 0 2}$ & $\mathbf{0 . 0 1}$ \\
\hline Eveleth & St. Louis & 212645 & 2.73 & 3.21 & 3.74 & 4.49 & 5.06 & 5.63 \\
Gull Lake & Cass & 213411 & 2.84 & 3.38 & 3.97 & 4.86 & 5.62 & 6.45 \\
Holyoke & Carlton & 213863 & 4.72 & 3.53 & 4.03 & 4.74 & 5.36 & 6.02 \\
Pokegama & Itasca & 216612 & 4.30 & 3.38 & 3.97 & 4.86 & 5.62 & 6.45 \\
Sandy Lake & Aitkin & 217460 & 6.27 & 3.53 & 4.03 & 4.74 & 5.36 & 6.02 \\
Wales & Lake & 218613 & 5.28 & 3.21 & 3.74 & 4.49 & 5.06 & 5.63 \\
\hline
\end{tabular}

${ }^{1}$ The annual exceedance probability is the probability that a given event will be exceeded or equaled in any given year. For example, the annual exceedance probability of the 100 -year rainfall is 0.01 . In other words, there is a 1-percent chance that the rainfall would be exceeded or equaled in any given year.

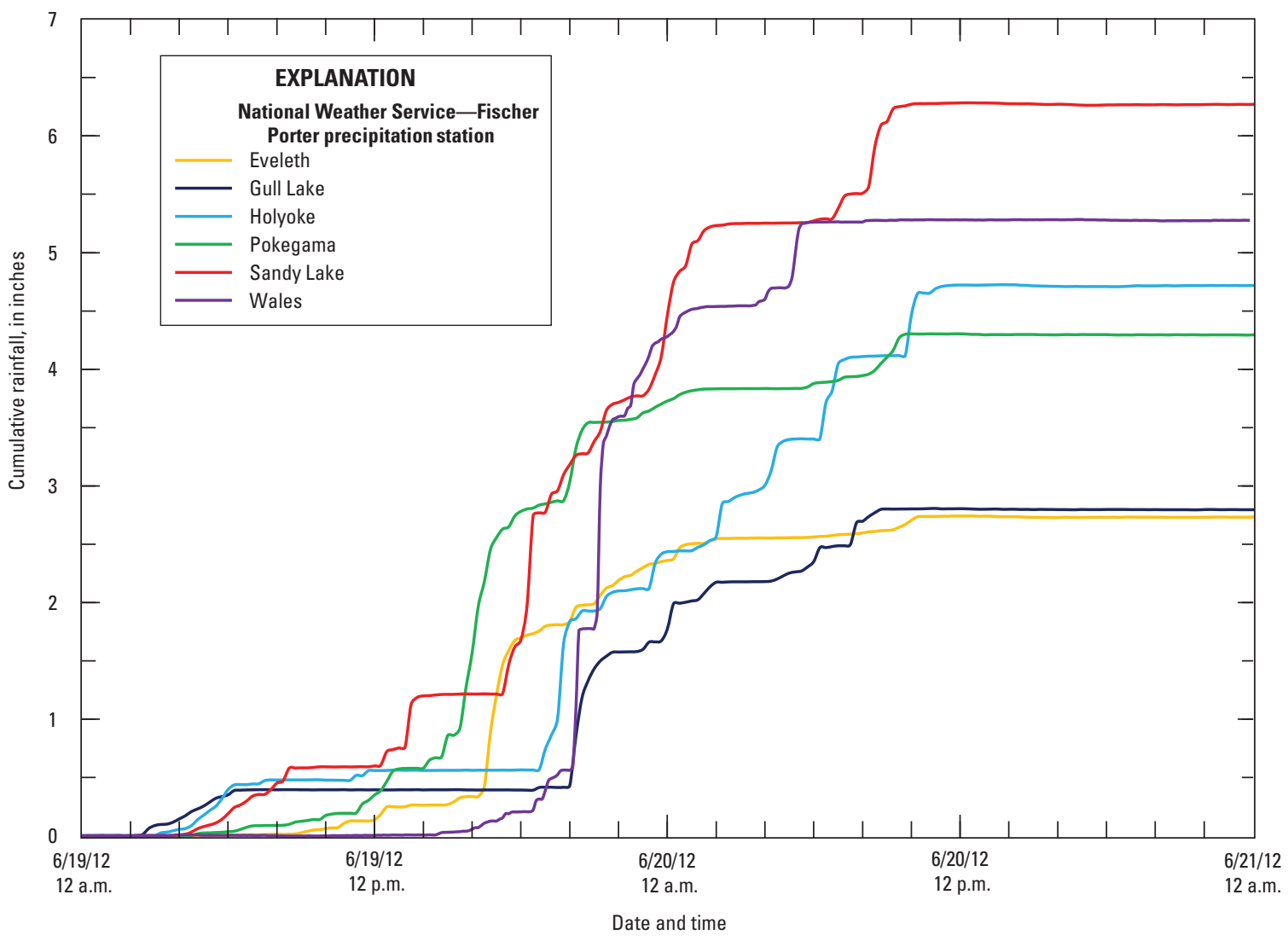

Figure 3. Cumulative daily rainfall during June 19-20, 2012, at selected National Weather Service (NWS) Cooperative Observing-Fischer Porter precipitation stations in northeastern Minnesota. 


\section{Methods}

The methods used to compute magnitudes and annual exceedance probabilities of peak streamflows and to collect high-water-mark data are described in this section of the report. Methods used to create flood-peak inundation maps and water-surface profiles also are described.

\section{Computing the Magnitudes of Peak Streamflows}

Peak streamflows documented in this study were determined at 35 USGS streamgages (19 continuous-record streamgages and 16 crest-stage gages; locations shown in fig. 4). Continuous-record streamgages record stream levels continuously and for those referred to in this report, data are recorded electronically and telemetered to USGS offices for processing in near real time. Crest-stage gages (CSGs) are partial-record, nonmechanical, nontelemetered gages intended to record only the peak (crest) stream level since the last site visit.

For both types of streamgages, the peak streamflow is determined by an empirical relation developed between the stream level (also referred to as stage or gage height) and streamflow (also referred to as discharge) unique to each location. These stage-discharge relations at streamgages are developed and maintained by relating paired measurements of stage (gage height) and streamflow over the range of streamflows through time. Paired measurements used to develop a stage-discharge relation are determined most commonly by direct measurement of stage (observed/recorded) and streamflow (velocity meter) at the streamgages (Rantz and others, 1982); or, if direct measurement is not possible, by indirect hydraulic methods (Benson and Dalrymple, 1967). The stage-discharge relation is developed using available stage/discharge measurements and controlling hydraulic features of the channel. Stage-discharge relations can be extrapolated slightly beyond the highest measurement of stage/streamflow, depending on available information about channel geometry and hydraulic conditions (Rantz and others, 1982).

Flood-peak gage heights were obtained either from electronic data recorders at continuous-record streamgages or from CSGs. At both types of streamgages, peak gage heights were confirmed by independent secondary streamgages or by nearby high-water marks left as the streams receded from flood peak. At a few streamgages that were inundated by flood waters, peak gage heights were determined from surveyed high-water marks near streamgages. The stage-discharge relation at each streamgage was used to compute peak streamflow from the flood-peak gage height. Direct or indirect streamflow measurements served as flood-event data points for stage-discharge relation verification and extrapolation.

\section{Estimating Annual Exceedance Probabilities of Peak Streamflows}

The annual exceedance probability (AEP) for a particular streamflow is the probability of that streamflow being equaled or exceeded in any given year. An AEP of 0.01 has a 1 in 100 chance or 1-percent risk of being equaled or exceeded in any given year (Holmes and Dinicola, 2010). The AEP is related to the traditional concept of recurrence interval; by definition, the recurrence interval corresponding to a particular AEP is equal to 1 divided by the AEP (American Society of Civil Engineers, 1953; Holmes and Dinicola, 2010).

Streamflows for selected AEPs $(0.10,0.04,0.02,0.01$, and 0.002 ) were estimated by using one of four methods: (1) the Bulletin 17B procedure presented by the Interagency Advisory Committee on Water Data (1982), (2) regional regression equations for rural conditions developed by Lorenz and others (2010), (3) the Expected Moments Algorithm (Cohn and others, 1997), or (4) weighting of independent estimates (WIE) procedure (Cohn and others, 2012; Interagency Advisory Committee on Water Data, 1982). Users of the Bulletin 17B procedure and regional regression equations for rural conditions calculate flood probabilities by fitting systematic annual peakstreamflow data to a log-Pearson type III (LPIII) distribution. The Expected Moments Algorithm is a generalization of the procedures in Bulletin 17B and was designed to better accommodate historical peak-flow data (known peak flows outside the period of continuous streamflow data collection) and leftcensored data (peak flows less than what can be measured at the streamgage). The WIE method is used to reduce uncertainty in the AEP by combining the at-site estimate with the regional regression estimate from Lorenz and others (2010) for records at sites that are unregulated, unaffected by urbanization, and have a drainage area less than 3,000 square miles $\left(\mathrm{mi}^{2}\right)$ (Lorenz and others, 2010; Cohn and others, 2012). The June 2012 peak streamflows can then be related to the AEPs for each streamgage, by bracketing the observed streamflow with the streamflow magnitudes associated with the selected AEPs.

\section{Collection of High-Water-Mark Data}

High-water marks record the observed elevation of the flood peak, and provide the data needed to estimate the maximum flood-inundation surface. High-water marks were identified and flagged to document inundation levels in selected communities most affected by flooding, in addition to the high-water marks described previously that were collected at streamgages to confirm peak discharges. These high-water marks were collected by staff from the USGS, USACE, and city of Duluth in northeastern Minnesota during June and July 2012 after floodwaters had receded. To ensure consistent methods were used to identify and document high-water marks, USGS staff met with and provided other agency staff with documentation of the methods used. 


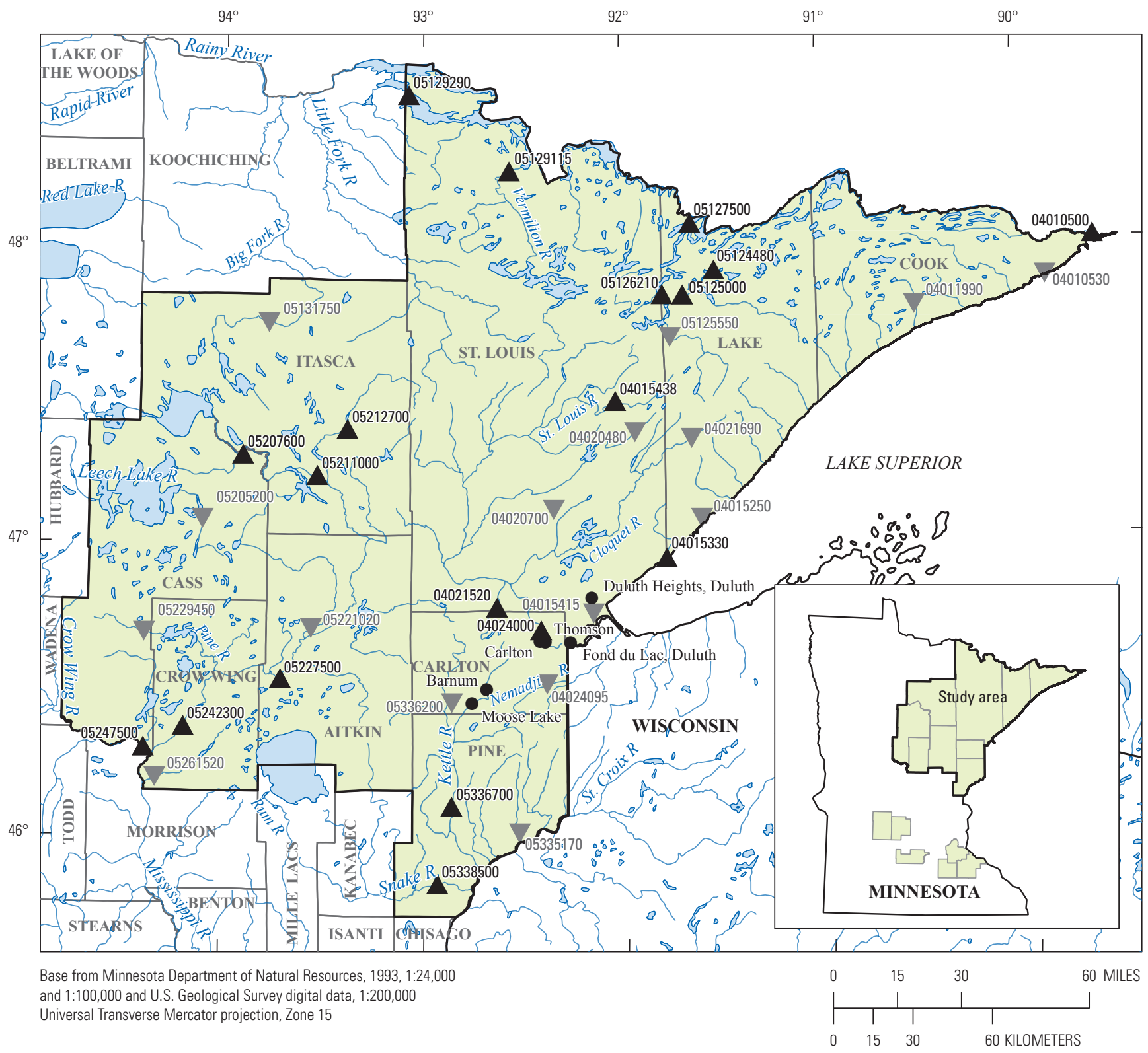

EXPLANATION

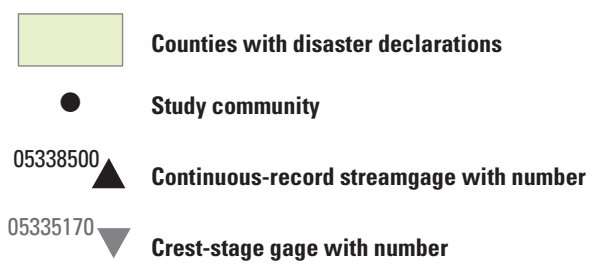

Figure 4. Locations of selected U.S. Geological Survey streamgages in the counties with disaster declarations for the floods of June 2012 in northeastern Minnesota. 
Common high-water marks included stain lines and debris buildup on buildings, trees, or other structures that identify the highest level reached by the flooding waters. The quality of the high-water marks was subjectively rated in the field as excellent, good, fair, or poor by the high-water-mark crews. Ratings were based on the clarity of the mark and visual or hand-level comparison to nearby marks.

The high-water marks collected by the USGS were surveyed using Real-Time Kinematic Global Positioning System (RTK-GPS). The survey used a network of continuously operating global positioning system (GPS) stations, known as the MnDOT CORS Network (http://www.dot.state. mn.us/surveying/CORS/CORS.html), that provides real-time correction to the rover GPS through a cellular data connection, thus eliminating the need for a base station setup. Each survey was calibrated to a nearby MnDOT benchmark. Benchmarks were chosen based on the vertical accuracy rating of order 2 or better, as the vertical position of the high-water-mark data was deemed most critical. In the case of Carlton, Thomson, and Moose Lake, the horizontal order of the nearby usable benchmarks were not established. The horizontal position of the RTK-GPS survey was then adjusted using a noncalibrated GPS measurement at the benchmark or visual correction from aerial imagery.

The preferred method of surveying was to set the RTKGPS rover up directly above the high-water mark. However, in many cases tree cover or building interference did not allow direct surveying of the high-water mark, and then a survey point was made a short distance away by transferring the elevation of the desired high-water mark to the survey point by using a hand level or string level. No correction for horizontal position was made. All USGS high-water marks were surveyed to an estimated vertical accuracy of 0.1 foot ( $\mathrm{ft}$ ), whereas the horizontal position may vary by as much as $15 \mathrm{ft}$.

The city of Duluth and the USACE Detroit District collected and surveyed high-water marks along Keene Creek (not shown), Kingsbury Creek (not shown), and Miller Creek, including in the Duluth Heights neighborhood of Duluth, using methods similar to the USGS collection and surveying methods. The USACE St. Paul District also provided highwater marks that are routinely collected during flood events, primarily at bridge structures and along roads, along selected rivers in the Mississippi and Kettle River Basins. The methods and accuracy of these data were not determined in this study. All high-water-mark data are included in appendix 1; table 1-1 contains the high-water marks for mapped communities of Barnum (Moose Horn River), Carlton (Otter Creek), Duluth Heights neighborhood of Duluth (Miller Creek), Fond du Lac neighborhood of Duluth (St. Louis River), Moose Lake (Moose Horn River and Moosehead Lake), and Thomson (Thomson Reservoir outflow near the St. Louis River), and table 1-2 contains the high-water marks for additional areas in northeastern Minnesota.

\section{Flood-Peak Inundation Maps}

Flood-peak inundation maps were produced from the high-water marks to show the extent and depth of the peak flooding. These maps were produced by use of geographic information system (GIS) software and associated programs (Morlock and others, 2008; Fitzpatrick and others, 2008; Fowler and others, 2010; Ellison and others, 2011), and a detailed description of the GIS process is described by Mastin and others (2010). The GIS layers of high-water-mark locations and elevations were used in conjunction with LiDARbased 1-meter land-surface elevation data files. LiDAR, an acronym for "light detection and ranging," is remote sensing technology that is based on discrete light pulses and measured traveltimes. It is used to generate highly accurate three-dimensional representations of the Earth's surface, termed "digital elevation models" (DEMs) (National Oceanic and Atmospheric Administration, 2008). These DEMs were used to develop the inundation maps, which then were superimposed on the corresponding National Agricultural Imagery Program aerial imagery (U.S. Department of Agriculture, 2010). Note that LiDAR topography represents "bare earth" elevations, such that houses in the flood plain and bridge decks over the river centerline are removed. Additionally, LiDAR measurements do not penetrate water, so the elevation in water bodies approximately represents the water surface at the time of the LiDAR collection flights.

Water-surface elevation was assigned to the stream centerline based on nearby high-water-mark data with a linear interpolation along the stream centerline between adjacent high-water marks. However, the actual water surface may have had a different profile than the linear interpolation, hence the inundation may have been somewhat different than the mapped results. This is especially true at structures where no high-watermark data were available; there may have been a sharper drop in the water-surface profile from the upstream to downstream side of a culvert or bridge structure. Cross-section lines were drawn across the valley representing a line of equal, potential peak water-surface elevation and, generally, were perpendicular to the direction of flow. A potential water-surface elevation was assigned to each cross section based on the water-surface elevation of the stream where they intersect. A triangular irregular network (TIN) was produced from the cross-section lines to produce a three-dimensional potential water surface. The terrain elevation (DEM) was subtracted from the potential water-surface elevation TIN, resulting in a GIS coverage where positive values represent the depth of inundation.

\section{Flood-Peak Water-Surface Profiles}

Standard USGS methods were used to develop floodpeak water-surface profiles from the high-water-mark elevations and locations (Benson and Dalrymple, 1967; Lumia and others, 1986). Flood profiles were produced for the mapped 
stream reaches for the six severely affected communities in northeastern Minnesota by plotting high-water-mark elevations by mile of stream as measured upstream on the centerline of the thalweg from the downstream boundary of each study reach. Because the flood-inundation in Thomson represented flow across the landscape, the profile was measured along an approximate centerline of the flow rather than along the nearby stream thalweg. The water surface between high-water marks was estimated by linear interpolation. A linear interpolation between high-water marks is an approximation of the actual water surface.

\section{Floods of June 2012 in Northeastern Minnesota}

The estimated AEPs of peak streamflows for the floods of June 2012 are presented in this section of the report. Floodpeak inundation maps and flood-peak water-surface profiles also are presented.

\section{Magnitudes and Estimated Annual Exceedance Probabilities of Peak Streamflows}

The magnitudes (flood-peak gage-height data and peak-streamflow data) and estimated AEPs from the June 2012 floods are presented for 34 of the 35 streamgages (table 2). The Mississippi River at Willow Beach at Ball Club (streamgage 05207600) does not have sufficient historical record to compute AEPs, and the basin characteristics are beyond the range applicable by the regression equations. New peak-of-record streamflows were recorded at 13 USGS streamgages as a result of the heavy rainfall, including the St. Louis River at Scanlon (streamgage 04024000), which has more than 100 years of streamflow records. Flood-peak streamflows in June 2012 had AEPs estimated to be less than 0.002 ( 0.2 percent; recurrence interval greater than 500 years) for five streamgages, and between 0.002 and 0.01 (1 percent; recurrence interval greater than 100 years) for four streamgages (table 2).

The timing of peak flows for streams of differing size is evident in the plot of the stage hydrographs for selected streamgages for the flood event (fig. 5). Streams and smaller rivers were quick to respond to the intense rainfall, such as the Knife River near Two Harbors (04015330), which peaked at an estimated 25,000 cubic feet per second $\left(\mathrm{ft}^{3} / \mathrm{s}\right)$ on June 20, 2012, exceeding the previous peak of record of 7,440 ft3/s from May 1979 (table 2). Some larger rivers also had rapid rises in streamflow in response to the intense rainfalls late on June 19, 2012, such as the St. Louis River at Scanlon (04024000), which peaked at 45,300 ft $\mathrm{ft}^{3} / \mathrm{s}$ on June 21, 2012 (table 2). Other large rivers, such as the Mississippi River, had a more delayed response time as the water accumulated from tributaries; the peaks also were affected by dam and reservoir management activities (fig. 5).

\section{Flood-Peak Inundation Maps and Water-Surface Profiles}

Flood-peak inundation maps (figs. 2-1 to 2-6 in appendix 2) and flood-peak water-surface profiles (figs. 3-1 to 3-6 in appendix 3) were produced for the six communities of Barnum (Moose Horn River), Carlton (Otter Creek), Duluth Heights neighborhood of Duluth (Miller Creek), Fond du Lac neighborhood of Duluth (St. Louis River), Moose Lake (Moose Horn River and Moosehead Lake), and Thomson (Thomson Reservoir outflow near the St. Louis River), respectively. Personnel from the USGS, USACE Detroit District, and city of Duluth flagged and surveyed high-water marks in June and July 2012 in these six most severely affected communities. The city of Duluth and the USACE Detroit District also surveyed high-water marks along Keene Creek (not shown), Kingsbury Creek (not shown), and the lower part of Miller Creek. The USACE St. Paul District collected high-water marks at bridge structures along the Mississippi River and Diversion Channel in the Mississippi River Basin, and along the Moose Horn, Kettle, Pine, and Willow Rivers in the Kettle River Basin. Descriptions of all the high-water marks are listed in appendix 1; only the locations of high-water marks in the six mapped communities are shown in the report figures.

A flood-peak inundation map was generated for each community showing the maximum extent and depth of floodwaters in and around the community (appendix 2). Inundation maps contain locations and elevations of the high-water marks, along with an indication of whether each high-water mark was used to develop the flood-peak water-surface. If a data point was substantially higher or lower when compared to neighboring points, the point in question was not used in interpolating the water surface for the inundation map. For example, high-water marks MOOSE1 and MOOSE2 (table 1-1) in the community of Moose Lake were substantially lower than other high-water marks in the area and were not used to interpolate the water surface for mapping the flood inundation (figs. 2-5 and 3-5). It is assumed that these marks were left as flood waters receded and were not representative of the peak water surface. In the Fond du Lac neighborhood of Duluth, numerous high-water marks were collected in proximity to each other; however, the elevations do not agree in connecting a single peak water-surface profile along the St. Louis River (figs. 2-4 and 3-4). The elevations from high-water-mark identifiers FDL1, FDL3, and FDL10 were used in the flood-inundation mapping for the upstream part of the profile, whereas the other nearby high-water marks that are all lower in elevation and likely not representative of the peak water surface were disregarded. Additionally, high-water-mark identifier FDL9 was on a hill with substantial flow heading downslope towards the St. Louis River, and was not used for the water-surface profile along the St. Louis River. 
Table 2. Provisional flood-peak gage heights, peak streamflows, and annual exceedance probabilities of peak streamflows during the floods of June 2012 at selected U.S. Geological Survey streamgages in northeastern Minnesota.

[mi² , square miles; ft, feet; NGVD 29, National Geodetic Vertical Datum of 1929; WY, water year; $\mathrm{ft}^{3} / \mathrm{s}$, cubic feet per second; \%, percent; Minn., Minnesota; e, estimated, >, greater than; <, less than; -- data not available]

\begin{tabular}{|c|c|c|c|c|c|c|c|c|c|c|c|c|c|}
\hline \multirow[b]{2}{*}{$\begin{array}{l}\text { Station } \\
\text { number }\end{array}$} & \multirow[b]{2}{*}{ Stream and community } & \multirow{2}{*}{$\begin{array}{c}\text { Drainage } \\
\text { area } \\
\left(\mathrm{mi}^{2}\right)\end{array}$} & \multirow{2}{*}{$\begin{array}{c}\text { Gage } \\
\text { vertical } \\
\text { datum } \\
\text { (ft above } \\
\text { NGVD 29) }\end{array}$} & \multirow{2}{*}{$\begin{array}{c}\text { Water } \\
\text { years' with } \\
\text { peak-flow } \\
\text { records }\end{array}$} & \multirow{2}{*}{$\begin{array}{c}\text { Length } \\
\text { of record } \\
\text { of annual } \\
\text { peaks } \\
\text { (years) }\end{array}$} & \multicolumn{3}{|c|}{$\begin{array}{l}\text { Peak flow for period of record prior } \\
\text { to WY } 2012\end{array}$} & \multicolumn{3}{|c|}{$\begin{array}{l}\text { Peak flow for June 19-30, } 2012 \\
\text { floods }\end{array}$} & \multirow{2}{*}{$\begin{array}{c}\text { Annual } \\
\text { exceedance } \\
\text { probability }{ }^{2} \\
\text { for June } 2012 \\
\text { peak streamflow }\end{array}$} & \multirow{2}{*}{$\begin{array}{c}\text { Estimated } \\
\text { streamflow } \\
\text { of } 0.01(1 \%) \\
\text { annual } \\
\text { exceedence } \\
\text { probability }\end{array}$} \\
\hline & & & & & & Date & $\begin{array}{l}\text { Gage height } \\
\text { (ft above } \\
\text { gage datum) }\end{array}$ & $\begin{array}{l}\text { Stream- } \\
\text { flow } \\
\left(\mathrm{ft}^{3} / \mathrm{s}\right)\end{array}$ & Date & $\begin{array}{l}\text { Gage height } \\
\text { (ft above } \\
\text { gage datum) }\end{array}$ & $\begin{array}{l}\text { Stream- } \\
\text { flow } \\
\left(\mathrm{ft}^{3} / \mathrm{s}\right)\end{array}$ & & \\
\hline 04010500 & $\begin{array}{l}\text { Pigeon River at Middle Falls near Grand } \\
\text { Portage, Minn. }\end{array}$ & 609 & 787.58 & 1924-2011 & 88 & $5 / 5 / 1934$ & 7.60 & 11,000 & $6 / 20 / 2012$ & 8.76 & 3,700 & $>0.10$ & ${ }^{3} 11,700$ \\
\hline${ }^{4} 04010530$ & Reservation River near Hovland, Minn. & 16.5 & 660.00 & $\begin{array}{l}1991-92 \\
2000-11\end{array}$ & 14 & $7 / 31 / 2009$ & 3.68 & $>1,350$ & $6 / 20 / 2012$ & 4.05 & 1,300 & $0.10-0.04$ & ${ }^{5} 2,130$ \\
\hline${ }^{4} 04011990$ & $\begin{array}{l}\text { Cascade River at Forest Road } 45 \text { near Grand } \\
\text { Marais, Minn. }\end{array}$ & 87.6 & $1,500.00$ & 1985-2011 & 27 & $4 / 24 / 2001$ & 13.36 & 1,810 & $6 / 20 / 2012$ & 11.38 & ${ }^{6} 671$ & $>0.10$ & ${ }^{5} 2,590$ \\
\hline${ }^{4} 04015250$ & Silver Creek tributary near Two Harbors, Minn. & 3.62 & Undetermined $^{7}$ & 1965-2011 & 47 & 9/20/1972 & 17.08 & 1,880 & 6/20/2012 & 17.50 & ${ }^{82,200}$ & $0.01-0.002$ & ${ }^{5} 1,890$ \\
\hline 04015330 & Knife River near Two Harbors, Minn. & 83.6 & Undetermined ${ }^{7}$ & $1975-2011$ & 37 & $5 / 10 / 1979$ & 11.16 & 7,440 & $6 / 20 / 2012$ & 12.81 & $8,925,000$ & $<0.002$ & ${ }^{59} 9,920$ \\
\hline${ }^{4} 04015415$ & $\begin{array}{l}\text { Lake Superior tributary at West 9th Street in } \\
\text { Duluth, Minn. }\end{array}$ & 1.81 & Undetermined $^{7}$ & $2001-11$ & 11 & $8 / 2 / 2010$ & 9.72 & 175 & $6 / 20 / 2012$ & 11.61 & ${ }^{8} 740$ & $<0.002$ & ${ }^{10} 226$ \\
\hline${ }^{11} 04015438$ & St. Louis River near Skibo, Minn. & 101 & $1,500.00$ & -- & -- & -- & -- & -- & $6 / 24 / 2012$ & 20.79 & ${ }^{8} 813$ & $>0.10$ & ${ }^{12} 1,800$ \\
\hline${ }^{4} 04020480$ & $\begin{array}{l}\text { North Branch Whiteface River near Fairbanks, } \\
\text { Minn. }\end{array}$ & 17.1 & Undetermined $^{7}$ & 1979-2011 & 33 & 4/23/1979 & 13.67 & 660 & $6 / 21 / 2012$ & 13.90 & 649 & $0.02-0.01$ & ${ }^{5} 700$ \\
\hline${ }^{4} 04020700$ & Bug Creek at Shaw, Minn. & 24.8 & Undetermined $^{7}$ & 1979-2011 & 33 & $7 / 5 / 1999$ & 18.00 & ${ }^{9} 1,350$ & $6 / 21 / 2012$ & 18.10 & ${ }^{8} 1,580$ & $0.01-0.002$ & ${ }^{5} 1,380$ \\
\hline 04021520 & $\begin{array}{l}\text { Stoney Brook at Pine Drive near Brookston, } \\
\text { Minn. }\end{array}$ & 74.0 & Undetermined $^{7}$ & $2005-11$ & 7 & $4 / 27 / 2008$ & 7.70 & 453 & $6 / 21 / 2012$ & 12.34 & ${ }^{8} 1,170$ & $0.02-0.01$ & ${ }^{12} 1,290$ \\
\hline${ }^{4} 04021690$ & Cloquet River near Toimi, Minn. & 40.8 & $1,700.00$ & $1986-2011$ & 26 & $7 / 4 / 1993$ & 9.06 & 1,540 & $6 / 21 / 2012$ & 8.30 & 1,110 & $0.04-0.02$ & ${ }^{5} 1,460$ \\
\hline 04024000 & St. Louis River at Scanlon, Minn. & 3,430 & $1,101.23$ & 1908-2011 & 104 & $5 / 9 / 1950$ & -- & ${ }^{13} 37,900$ & $6 / 21 / 2012$ & 16.62 & ${ }^{8} 45,300$ & $<0.002$ & 338,400 \\
\hline${ }^{4} 04024095$ & Nemadji River near Holyoke, Minn. & 127 & 756.12 & 1972-2011 & 40 & $8 / 3 / 2011$ & 18.60 & 5,300 & $6 / 20 / 2012$ & 21.05 & ${ }^{8,9} 9,700$ & $<0.002$ & ${ }^{5} 5,830$ \\
\hline 05124480 & Kawishiwi River near Ely, Minn. & 254 & Undetermined ${ }^{7}$ & 1967-2011 & 45 & $5 / 4 / 2001$ & 6.07 & 1,870 & $6 / 24 / 2012$ & 4.91 & 793 & $>0.10$ & ${ }^{5} 2,540$ \\
\hline 05125000 & South Kawishiwi River near Ely, Minn. & -- & $1,430.00$ & $\begin{array}{l}\text { 1952-61 } \\
\text { 1976-78 } \\
2003-11\end{array}$ & 22 & $4 / 21 / 1976$ & 7.18 & 4,980 & $6 / 26 / 2012$ & 5.69 & 2,560 & $>0.10$ & ${ }^{10} 8,000$ \\
\hline${ }^{4} 05125550$ & Stony River near Babbitt, Minn. & 215 & Undetermined $^{7}$ & $\begin{array}{c}1976-80 \\
1986-2011\end{array}$ & 31 & $4 / 19 / 1976$ & 8.71 & 2,490 & $6 / 26 / 2012$ & 7.31 & 1,480 & $>0.10$ & ${ }^{5} 3,090$ \\
\hline 05126210 & $\begin{array}{l}\text { South Kawishiwi River above White Iron Lake } \\
\text { near Ely, Minn. }\end{array}$ & 837 & Undetermined ${ }^{7}$ & $\begin{array}{l}1976-78 \\
2003-11\end{array}$ & 12 & $4 / 22 / 1976$ & 11.42 & 8,080 & $6 / 26 / 2012$ & 9.49 & 4,890 & $>0.10$ & ${ }^{3} 12,700$ \\
\hline 05127500 & Basswood River near Winton, Minn. & 1,740 & $1,296.80$ & $\begin{array}{l}1926-27 \\
1930-2011\end{array}$ & 84 & $5 / 24 / 1950$ & 6.94 & ${ }^{13} 15,600$ & $6 / 30 / 2012$ & 5.59 & 4,370 & $>0.10$ & ${ }^{3} 12,400$ \\
\hline 05129115 & Vermilion River near Crane Lake, Minn. & 905 & $1,180.00$ & 1979-2011 & 33 & $4 / 1979$ & 15.15 & 4,600 & $6 / 21 / 2012$ & 10.20 & ${ }^{6} 1,520$ & $>0.10$ & ${ }^{5} 5,660$ \\
\hline 05129290 & $\begin{array}{l}\text { Gold Portage outlet from Kabetogama Lake } \\
\text { near Ray, Minn. }\end{array}$ & -- & Undetermined $^{7}$ & $\begin{array}{l}\text { 1983-94, } \\
1998-2011\end{array}$ & 26 & $5 / 29 / 2001$ & $\left({ }^{14}\right)$ & 1,310 & $6 / 21 / 2012$ & 18.38 & ${ }^{6} 770$ & $>0.10$ & ${ }^{3} 1,320$ \\
\hline${ }^{4} 05131750$ & Big Fork River near Bigfork, Minn. & 606 & Undetermined $^{7}$ & 1973-2011 & 38 & 4/22/1979 & 15.48 & 2,830 & $6 / 21 / 2012$ & $<10.59$ & 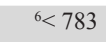 & $>0.10$ & ${ }^{5} 3,150$ \\
\hline${ }^{4} 05205200$ & Boy River near Remer, Minn. & 289 & Undetermined 7 & 1986-2011 & 26 & $7 / 23 / 1987$ & 11.64 & 660 & $6 / 22 / 2012$ & 11.14 & 420 & $>0.10$ & ${ }^{5} 1,040$ \\
\hline 05207600 & $\begin{array}{l}\text { Mississippi River at Willow Beach at Ball } \\
\text { Club, Minn. }\end{array}$ & 2,850 & Undetermined ${ }^{7}$ & $2008-11$ & 4 & $2 / 18 / 2011$ & ${ }^{14,15} 11.50$ & ${ }^{13} 2,720$ & $6 / 24 / 2012$ & 8.71 & ${ }^{6} 1,410$ & Undetemined $^{16}$ & Undetemined $^{16}$ \\
\hline 05211000 & Mississippi River at Grand Rapids, Minn. & 3,370 & $1,242.03$ & 1942-2011 & 70 & $9 / 3 / 1948$ & 15.20 & ${ }^{13} 12,500$ & $6 / 19 / 2012$ & 8.41 & ${ }^{6} 3,190$ & $>0.10$ & ${ }^{10} 4,740$ \\
\hline 05212700 & Prairie River near Taconite, Minn. & 371 & $1,294.81$ & $\begin{array}{l}1968-83 \\
2001-11\end{array}$ & 27 & $4 / 17 / 1969$ & 11.81 & 3,260 & $6 / 27 / 2012$ & 7.91 & ${ }^{6} 942$ & $>0.10$ & ${ }^{5} 4,860$ \\
\hline
\end{tabular}


Table 2. Provisional flood-peak gage heights, peak streamflows, and annual exceedance probabilities of peak streamflows during the floods of June 2012 at selected U.S. Geological Survey streamgages in northeastern Minnesota.-Continued

[mi², square miles; ft, feet; NGVD 29, National Geodetic Vertical Datum of 1929; WY, water year; ft³/s, cubic feet per second; \%, percent; Minn., Minnesota; e, estimated, >, greater than; <, less than; ,-- data not available]

\begin{tabular}{|c|c|c|c|c|c|c|c|c|c|c|c|c|c|}
\hline \multirow[b]{2}{*}{$\begin{array}{l}\text { Station } \\
\text { number }\end{array}$} & \multirow[b]{2}{*}{ Stream and community } & \multirow[b]{2}{*}{$\begin{array}{c}\text { Drainage } \\
\text { area } \\
\left(\mathrm{mi}^{2}\right)\end{array}$} & \multirow{2}{*}{$\begin{array}{c}\text { Gage } \\
\text { vertical } \\
\text { datum } \\
\text { (ft above } \\
\text { NGVD 29) }\end{array}$} & \multirow{2}{*}{$\begin{array}{c}\text { Water } \\
\text { years' with } \\
\text { peak-flow } \\
\text { records }\end{array}$} & \multirow{2}{*}{$\begin{array}{c}\text { Length } \\
\text { of record } \\
\text { of annual } \\
\text { peaks } \\
\text { (years) }\end{array}$} & \multicolumn{3}{|c|}{$\begin{array}{c}\text { Peak flow for period of record prior } \\
\text { to WY } 2012 \\
\end{array}$} & \multicolumn{3}{|c|}{$\begin{array}{l}\text { Peak flow for June 19-30, } 2012 \\
\text { floods }\end{array}$} & \multirow{2}{*}{$\begin{array}{c}\text { Annual } \\
\text { exceedance } \\
\text { probability }{ }^{2} \\
\text { for June } 2012 \\
\text { peak streamflow }\end{array}$} & \multirow{2}{*}{$\begin{array}{c}\text { Estimated } \\
\text { streamflow } \\
\text { of } 0.01(1 \%) \\
\text { annual } \\
\text { exceedence } \\
\text { probability }\end{array}$} \\
\hline & & & & & & Date & $\begin{array}{l}\text { Gage height } \\
\text { (ft above } \\
\text { gage datum) }\end{array}$ & $\begin{array}{l}\text { Stream- } \\
\text { flow } \\
\left(\mathrm{ft}^{3} / \mathrm{s}\right)\end{array}$ & Date & $\begin{array}{l}\text { Gage height } \\
\text { (ft above } \\
\text { gage datum) }\end{array}$ & $\begin{array}{l}\text { Stream- } \\
\text { flow } \\
\left(\mathrm{ft}^{3} / \mathrm{s}\right)\end{array}$ & & \\
\hline${ }^{4} 05221020$ & Willow River below Palisade, Minn. & 523 & ${\text { Undetermined }{ }^{7}}$ & $1972-2011$ & 40 & $4 / 25 / 1979$ & 17.25 & 3,730 & 6/28/2012 & 17.43 & 3,440 & $0.10-0.04$ & ${ }^{5} 4,820$ \\
\hline 05227500 & Mississippi River at Aitkin, Minn. & 6,140 & $1,182.41$ & $\begin{array}{c}1888-99 \\
1902-2011\end{array}$ & 112 & $5 / 20 / 1950$ & 22.49 & ${ }^{13} 20,000$ & $6 / 28 / 2012$ & 18.71 & 15,100 & $0.04-0.02$ & ${ }^{3} 16,400$ \\
\hline${ }^{4} 05229450$ & Pine River near Pine River, Minn. & 261 & $1,279.00$ & 1986-2011 & 26 & $5 / 14 / 1999$ & 5.15 & 1,520 & 6/23/2012 & 5.74 & ${ }^{8,9} 2,000$ & $0.01-0.002$ & ${ }^{5} 1,900$ \\
\hline 05242300 & Mississippi River at Brainerd, Minn. & 7,320 & $1,146.96$ & 1988-2011 & 24 & $4 / 30 / 2001$ & 16.70 & ${ }^{13} 17,500$ & $6 / 28 / 2012$ & 17.61 & ${ }^{8} 17,900$ & $0.02-0.01$ & ${ }^{10} 19,100$ \\
\hline 05247500 & Crow Wing River near Pillager, Minn. & 3,760 & $1,151.00$ & $\begin{array}{l}1965,1969 \\
1970-2011\end{array}$ & 43 & $4 / 14 / 1965$ & & ${ }^{13} 18,300$ & $6 / 24 / 2012$ & 7.35 & ${ }^{6} 6,860$ & $>0.10$ & ${ }^{3} 20,600$ \\
\hline${ }^{4} 05261520$ & Nokasippi River near Fort Ripley, Minn. & 193 & Undetermined $^{7}$ & $1986-2011$ & 26 & 6/26/2003 & 15.17 & 1,160 & $6 / 22 / 2012$ & 15.10 & ${ }^{8} 1,200$ & $0.10-0.04$ & ${ }^{5} 1,740$ \\
\hline${ }^{4} 05335170$ & Crooked Creek near Hinckley, Minn. & 94.4 & Undetermined ${ }^{7}$ & 1986-2011 & 26 & $4 / 23 / 2001$ & 16.65 & 2,100 & $6 / 22 / 2012$ & 15.02 & ${ }^{6} 1,380$ & $>0.10$ & ${ }^{5} 2,790$ \\
\hline${ }^{4} 05336200$ & Glaisby Brook near Kettle River, Minn. & 27.0 & $1,105.00$ & $1960-2011$ & 52 & $7 / 22 / 1972$ & 10.18 & 1,370 & 6/20/2012 & 12.26 & $8.9>2,000$ & $0.01-0.002$ & ${ }^{5} 1,520$ \\
\hline 05336700 & Kettle River below Sandstone, Minn. & 868 & 931.50 & $\begin{array}{c}1965 \\
1968-2011\end{array}$ & 45 & $7 / 23 / 1972$ & 15.38 & 17,200 & $6 / 22 / 2012$ & 18.22 & ${ }^{8} 24,800$ & $<0.002$ & ${ }^{5} 17,900$ \\
\hline 05338500 & Snake River near Pine City, Minn. & 974 & Undetermined $^{7}$ & $\begin{array}{c}\text { 1914-17, } \\
1950, \\
1952-2011\end{array}$ & 61 & 7/27/1972 & 10.38 & 14,300 & 6/26/2012 & 5.66 & ${ }^{6} 2,930$ & $>0.10$ & ${ }^{5} 15,300$ \\
\hline
\end{tabular}

${ }^{1}$ A water year is the 12-month period from October 1 through September 30 and is designated by the calendar year in which it ends. For some sites, records include annual peak-flow data only.

${ }^{2}$ The annual exceedance probability is the probability that a given event magnitude will be equaled or exceeded in any given year and is the reciprocal of the recurrence interval. The recurrence interval is the average interval of time within which the given flood will be equaled or exceeded once (American Society of Civil Engineers, 1953, p. 1221). The annual exceedance probability for a recurrence interval of 10 years is $0.10(10 \%)$; for 25 years, $0.04(4 \%)$; for 50 years, $0.02(2 \%)$; and for 100 years, $0.01(1 \%)$.

${ }^{3}$ Streamflow computed from Expected Moments Algorithm (Cohn and others, 1997).

${ }^{4}$ U.S. Geological Survey crest-stage or peak-stage gage.

${ }^{5}$ Streamflow from weighting of independent estimates (WIE) procedure (Interagency Advisory Committee on Water Data, 1982, appendix 8). The independent estimates were based on Lorenz and others (2010).

${ }^{6}$ June 2012 peak was not peak of water year 2012.

${ }^{7}$ Elevation from vertical datum has not been established.

${ }^{8}$ New streamflow peak of record.

${ }^{9}$ Streamflow is an estimate.

${ }^{10}$ Streamflow computed from Bulletin 17B, Guidelines for Determining Flood Flow Frequency (Interagency Advisory Committee on Water Data, 1982).

${ }^{11}$ Streamgage was installed August 2011.

${ }^{12}$ Streamflow from Lorenz and others (2010) regression equations.

${ }^{13}$ Streamflow affected to unknown degree by regulation or diversion.

${ }^{14} \mathrm{Gage}$ height not the maximum for the year.

${ }^{15} \mathrm{Gage}$ height affected by backwater.

${ }^{16}$ Recurrence-interval flows have not been established. One or more basin characteristics are beyond the range used for development of models from regression analysis. 


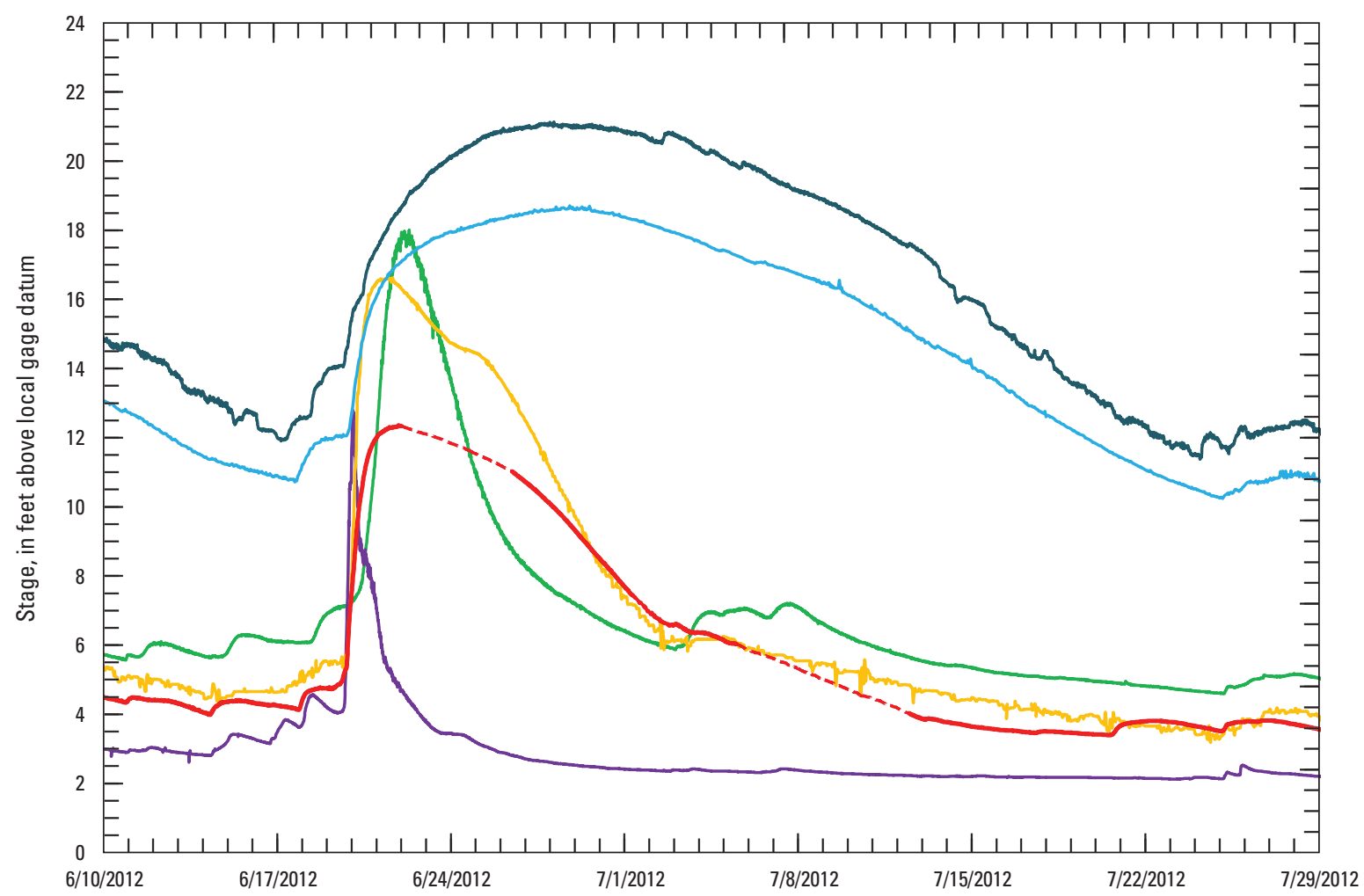

EXPLANATION
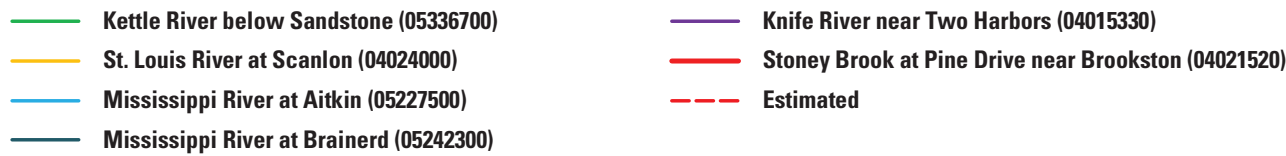

Figure 5. Provisional stage hydrographs at selected U.S. Geological Survey streamgages in northeastern Minnesota for June 10 through July 29, 2012.

The maps were checked by USGS surveying and high-water-mark personnel, and the high-water marks were compared spatially to check for mathematical or other errors. Anecdotal information from local residents was used to interpret the water-surface profile between high-water marks and to extrapolate the area of inundation beyond the surveyed area as necessary. The maps also were visually compared to photographs and videos of flooding available online and from local residents, as well as aerial photographs taken by MnDOT personnel from a helicopter during the flooding. Not all photographs and videos were taken during peak flooding and they are indicative of the minimum area that was flooded. Aerial photographs were used to extrapolate the maps beyond the extent of surveyed high-water marks; for example, the inundation in Fond du Lac neighborhood of Duluth extended downstream and to the north away from the river corridor where most high-water marks were found and surveyed. The elevation and extent of the flood waters were inferred from the MnDOT aerial photographs at easily identifiable edges of water across the roadways.

Flood-peak water-surface profiles were produced from the high-water-mark data along the thalweg (appendix 3 ).
The profiles include only the high-water marks that were used to determine the elevation of the flood-peak water-surface (appendix 2). The only exception is that the water-surface profile for Thomson does not include high-water-marks ETHOM1 and ETHOM2, which were used to map the water-surface elevation of the east side of town but are not adjacent to the primary flow path that is represented in the water-surface profile (figs. 2-6 and 3-6). Flood-peak profiles show how the flood-peak inundation surface and slope varied along the stream reach through each of the six communities. Locations of bridge crossings were added to the profiles to provide additional context.

Although few high-water marks were identified in Barnum (fig. 2-1), photographs taken by residents during the floods also provided information on what areas of town were flooded by the Moose Horn River. Southwest of town, inundation was mapped by assuming that floodwaters spilled out of the channel and backed up this drainage area that normally flows north into the Moose Horn River during low-flow conditions.

The city of Carlton also is located near Thomson Reservoir; however, flooding in Carlton originated from Otter Creek 
on the south side of town. Otter Creek flows east until it joins the St. Louis River downstream of Thomson Reservoir. As the floodwaters in Otter Creek rose, they spilled northward across the train tracks and flowed through town along two pathways (fig. 2-2). The floodwaters likely flowed north of town, then turned and flowed east along a drainage path south of Thomson Reservoir.

The flooding in the Duluth Heights neighborhood in Duluth was from Miller Creek, and affected businesses along Miller Trunk Highway (fig. 2-3). Parts of Miller Trunk Highway were inundated and the road was temporarily closed.

Also in Duluth, the Fond du Lac neighborhood was substantially inundated by the St. Louis River (fig. 2-4). Floodwaters inundated most residences along the north side of the river. Highway 23 was underwater in several locations and was closed to traffic.

The town of Moose Lake was flooded along Moosehead Lake on the Moose Horn River (fig. 2-5). Much of the rain that contributed to flooding in Moose Lake fell on the contributing watershed farther upstream. The Moose Horn River enters the northeast corner of Moosehead Lake, and exits in its southwest corner. The Portage River also is tributary to Moosehead Lake, entering at the east side. The water surface of the lake was mapped at an elevation of 1,052.5 ft for the entire area of the expanded lake. Floodwaters inundated houses, schools, and a campground.

The St. Louis River exits Thomson Reservoir (fig. 2-6) at the dam west of the town of Thompson. Although the flooding along the St. Louis River washed out part of the Highway 210 roadway, this area was not in the study area for inundation mapping. Floodwaters spilled out of Thomson Reservoir at several small dam structures and flowed overland into the town of Thomson. The more destructive floodwaters flowed overland and south along Vermillion Street, flooding houses and causing substantial damage to the street. This water continued to flow southeast across Highway 210 and joined the St. Louis River south of the study limit (fig. 2-6). On the eastern side of Thomson, the floodwaters flowed down the forested hill from the reservoir and flooded houses along Dalles Avenue. Two culverts at the study boundary (indicated by the deeper inundation depths at the southern study boundary on fig. 2-6) could not pass all the flow to the south, which backed up water and caused it to flow west along Dalles Avenue and join with the floodwaters from Vermillion Street. Farther to the east, a diversion canal that conveys water from Thomson Reservoir downstream to Minnesota Power facilities also was beyond the study limit.

\section{Description of Flood Damages and Effects}

Heavy rainfall on already saturated land caused widespread flash flooding and river flooding in northeastern
Minnesota in June 2012. Transportation disruptions were widespread, and road closures were common across Itasca, Aitkin, Carlton, southern Lake, and southern St. Louis Counties. Damages included residences, infrastructure, businesses, public parks, and recreation facilities. The most severely affected communities, and the focus of this study for inundation mapping, included Barnum (Moose Horn River), Carlton (Otter Creek), Duluth Heights neighborhood of Duluth (Miller Creek), Fond du Lac neighborhood of Duluth (St. Louis River), Moose Lake (Moose Horn River and Moosehead Lake), and Thomson (Thomson Reservoir outflow near the St. Louis River). Nearby communities such as Floodwood (not shown), Fond du Lac Indian Reservation (not shown), and Cloquet (not shown) also received extensive flooding and damage and were inspected by field crews but were beyond the scope of this study and not surveyed for high-water marks.

The floods in northeastern Minnesota caused more than an estimated \$100 million dollars in damages. Following is a summary of damage assessment compiled after June 2012 primarily from news releases and information by the Minnesota Department of Public Safety, Homeland Security and Emergency Management (2012):

- Road closures included Interstate 35 through Duluth and south of Carlton, as well as numerous State highways and local roads.

- Evacuations included Barnum, Thomson, and part of Moose Lake (Carlton County), parts of Fond du Lac neighborhood of Duluth, and Willow River (not shown; Pine County).

- Evacuation sites were set up in Duluth, Carlton, Scanlon (not shown), and Askov (not shown).

- Red Cross staffed evacuation sites, and Salvation Army provided meals.

- Food and drinking-water distribution points were set up in the affected areas.

- The Lake Superior Zoo in Duluth experienced damage as Kingsbury Creek (not shown) flooded, including the loss of 14 animals and damage of structures. Several other animals were swept from their enclosures but were safely rescued (Lake Superior Zoo, 2012).

- Jay Cooke State Park (not shown) was closed due to severe damage to the entrance route on Highway 210 . The park's iconic swinging bridge over the St. Louis River was severely damaged.

- Other parks (not shown on maps) were temporarily closed or had restricted access, including Savanna Portage State Park, Moose Lake State Park, Willard Munger State Trail, Cuyuna Country State Recreation Area, and Soo Line and Blind Lake ATV trails in Aitkin County. 
Preliminary damage assessments were done in 13 counties and the Fond du Lac Indian Reservation in the days after the flood. Assessment teams included Federal officials from FEMA, State officials from MHSEM, and local officials. On July 6, 2012, President Obama declared a major disaster existed in northeastern and central Minnesota for the June 14-21, 2012, storm and flood events (Federal Emergency Management Agency, 2012). The disaster declaration brought much needed additional assistance for residents and businesses. This declaration made public assistance requested by the Governor available to State and eligible local governments, and certain private nonprofit organizations on a costsharing basis for emergency work and the repair or replacement of facilities damaged by the severe flooding in Aitkin, Carlton, Cass, Cook, Crow Wing, Dakota, Goodhue, Itasca, Kandiyohi, Lake, Meeker, Pine, Rice, St. Louis, and Sibley Counties, as well as the Fond du Lac (not shown), Grand Portage (not shown), and Mille Lacs (not shown) Indian Reservations. This declaration also made Hazard Mitigation Grant Program assistance requested by the Governor available for hazard-mitigation measures statewide.

\section{Summary}

During June 19-20, 2012, heavy rainfall, as much as 10 inches locally reported, caused severe flooding across northeastern Minnesota. The floods were exacerbated by wet antecedent conditions from a relatively rainy spring, with May 2012 as one of the wettest Mays on record in Duluth. The June 19-20, 2012, rainfall event set new records in Duluth, including greatest 2-day precipitation with 7.25 inches of rain. The heavy rains fell on three major watersheds: the Mississippi Headwaters; the St. Croix, which drains to the Mississippi River; and Western Lake Superior, which includes the St. Louis River and other tributaries to Lake Superior. Widespread flash and river flooding in northeastern Minnesota that resulted from the heavy rainfall caused more than $\$ 100$ million dollars in damages. In all, nine counties in northeastern Minnesota were declared Federal disaster areas as a result of the flooding. The June 2012 flooding caused widespread transportation disruptions across Itasca, Aitkin, Carlton, southern Lake, and southern St. Louis Counties. Damages included residences, infrastructure, businesses, public parks, and recreation facilities.

Peak-of-record streamflows were recorded at 13 U.S. Geological Survey streamgages as a result of the heavy rainfall. Flood-peak gage heights, peak streamflows, and annual exceedance probabilities were tabulated for 35 U.S. Geological Survey streamgages. Flood-peak streamflows in June 2012 had annual exceedance probabilities estimated to be less than 0.002 ( 0.2 percent; recurrence interval greater than 500 years) for five streamgages, and between 0.002 and 0.01 (1 percent; recurrence interval greater than 100 years) for four streamgages. High-water marks were identified and tabulated for the most severely affected communities of Barnum (Moose Horn River), Carlton (Otter Creek), Duluth Heights neighborhood of Duluth (Miller Creek), Fond du Lac neighborhood of Duluth (St. Louis River), Moose Lake (Moose Horn River and Moosehead Lake), and Thomson (Thomson Reservoir outflow near the St. Louis River). Flood-peak inundation maps and water-surface profiles were produced for these six severely affected communities. The inundation maps were constructed in a geographic information system by combining high-water-mark data with high-resolution digital elevation model data. The flood maps and profiles show the extent and depth of flooding through the communities and can be used for flood response and recovery efforts by local, county, State, and Federal agencies.

\section{References Cited}

American Society of Civil Engineers, 1953, Report of the subcommittee on the joint division committee on floods: American Society of Civil Engineers Transactions, v. 118, p. 1,220-1,230.

Benson, M.A., and Dalrymple, Tate, 1967, General field and office procedures for indirect measurements: U.S. Geological Survey Techniques of Water-Resources Investigations, book 3, chap. A1, 30 p.

Charlton, Ro, 2009, Fundamentals of fluvial geomorphology: New York, Routledge, 234 p.

Cohn, T.A., Berenbrock, Charles, Kiang, J.E., and Mason, R.R., Jr., 2012, Calculating weighted estimates of peak streamflow statistics: U.S. Geological Survey Fact Sheet 2012-3038, 4 p. (Also available at http://pubs.usgs.gov/ $f_{s} / 2012 / 3038 /$.)

Cohn, T., Lane, W.L., and Baier, W.G., 1997, An algorithm for computing moments-based flood estimates when historical flood information is available: Water Resources Research, v. 33, no. 9, p. 2,089-2,096.

Ellison, C.A., Sanocki, C.A., Lorenz, D.L., Mitton, G.B., and Kruse, G.A., 2011, Floods of September 2010 in Southern Minnesota: U.S. Geological Survey Scientific Investigations Report 2011-5045, 37 p., 3 app. (Also available at http:// pubs.usgs.gov/sir/2011/5045/.)

Federal Emergency Management Agency, 2012, Minnesota severe storms and flooding (DR-4069): accessed October 19, 2012, at http://www.fema.gov/disaster/4069.

Fitzpatrick, F.A., Peppler, M.C., Walker, J.F., Rose, W.J., Waschbusch, R.J., and Kennedy, J.L., 2008, Flood of June 2008, southern Wisconsin: U.S. Geological Survey Scientific Investigations Report 2008-5235, 24 p. (Also available at http://pubs.usgs.gov/sir/2008/5235/.) 
Fowler, K.K., Kim, M.H., Menke, C.D., and Arvin, D.V., 2010, Flood of September 2008 in northwestern Indiana: U.S. Geological Survey Open-File Report 2010-1098, 20 p. (Also available at http://pubs.usgs.gov/of/2010/1098/.)

Graning, Amanda, and Hluchan, Rick, 2012, Summary of Duluth flash flood event, June 19th-20th 2012: Duluth, Minn., National Weather Service, 5 p., accessed October 19, 2012, at http://www.crh.noaa.gov/images/dlh/ StormSummaries/2012/June19 flood/DuluthSummary.pdf.

Holmes, R.R., Jr., Dinicola, Karen, 2010, 100-Year flood-It's all about chance: U.S. Geological Survey General Information Product 106, 1 sheet. (Also available at http://pubs. usgs.gov/gip/106/.)

Huff, F.A., and Angel, J.R., 1992, Rainfall frequency atlas of the Midwest: Champaign, Illinois State Water Survey, Bulletin $71,141 \mathrm{p}$.

Interagency Advisory Committee on Water Data, 1982, Guidelines for determining flood flow frequency, Bulletin 17B of the Hydrology Subcommittee: Reston, Virginia, U.S. Geological Survey, Office of Water Data Coordination, 183 p.

Lake Superior Zoo, 2012, Support your zoo: accessed December 6, 2012, at http://lszoo.org/support.htm.

Langbein, W.B., and Iseri, K.T., 1960, General introduction and hydrologic definitions, Manual of hydrology, part 1, General surface-water techniques: U.S. Geological Survey Water-Supply Paper 1541-A, 29 p.

Lorenz, D.L., Sanocki, C.A., and Kocian, M.J., 2010, Techniques for estimating the magnitude and frequency of peak flows on small streams in Minnesota based on data through water year 2005: U.S. Geological Survey Scientific Investigations Report 2009-5250, 54 p.

Lumia, Richard, Burke, P.M., and Johnston, W.H., 1986, Flooding of December 29, 1984, through January 2, 1985, in northern New York State, with flood profiles of the Black and Salmon Rivers: U.S. Geological Survey WaterResources Investigations Report 86-4191, 53 p.

Mastin, M.C., Gendaszek, A.S., and Barnas, C.R., 2010, Magnitude and extent of flooding at selected river reaches in western Washington, January 2009: U.S. Geological Survey Scientific Investigations Report 2010-5177, 34 p. (Also available at http://pubs.usgs.gov/sir/2010/5177/.)

Minnesota Department of Natural Resources State Climatology Office, 2012a, Wet May 2012: accessed October 29, 2012, at http://climate.umn.edu/doc/journal/ wet_may2012.htm.

Minnesota Department of Natural Resources State Climatology Office, 2012b, Flooding rains-June 14, 2012: accessed October 29, 2012, at http://climate.umn.edu/doc/journal/ flood14_150612.htm.
Minnesota Department of Natural Resources State Climatology Office, 2012c, Wet growing season in eastern Minnesota: accessed October 29, 2012, at http://climate.umn.edu/ doc/journal/wet_2012.htm.

Minnesota Department of Natural Resources State Climatology Office, 2012d, Flooding rains in northeast Minnesota: June 19-20, 2012: accessed October 29, 2012, at http:// climate.umn.edu/doc/journal/duluth_flooding_120620.htm.

Minnesota Department of Public Safety, Homeland Security and Emergency Management, 2012, 2012 Northeast and central Minnesota flooding (DR-4069): accessed November 26, 2012, at https://dps.mn.gov/divisions/hsem/minnesotarecovers/Pages/june-2012-flooding.aspx.

Minnesota Department of Transportation, 2012, MnDOT CORS GPS Network: accessed December 6, 2012, at http:// www.dot.state.mn.us/surveying/CORS/CORS.html.

Morlock, S.E., Menke, C.D., Arvin, D.V., and Kim, M.H., 2008, Flood of June 7-9, 2008, in central and southern Indiana: U.S. Geological Survey Open-File Report 20081322, 15 p., 3 app. (Also available at http://pubs.usgs.gov/ of $/ 2008 / 1322 /$.)

National Oceanic and Atmospheric Administration, 2008, LIDAR 101-An introduction to LiDAR technology, data, and applications: accessed November 26, 2012, at http:// www.csc.noaa.gov/digitalcoast/_pdf/What_is_Lidar.pdf.

National Weather Service, 2009, National Weather Service glossary: accessed October 29, 2012, at http://www.weather. gov/glossary/.

Rantz, S.E., and others, 1982, Measurement and computation of streamflow-Volume 1, Measurement of stage and discharge, and volume 2, Computation of discharge: U.S. Geological Survey Water-Supply Paper 2175, 631 p.

Skinner, K.D., 2009, Evaluation of LiDAR-acquired bathymetric and topographic data accuracy in various hydrogeomorphic settings in the lower Boise River, southwestern Idaho, 2007: U.S. Geological Survey Scientific Investigations Report 2009-5260, 12 p. (Also available at http:// pubs.usgs.gov/sir/2011/5051/.)

U.S. Department of Agriculture, 2010, National Agricultural Imagery Program (NAIP) digital orthorectified images (DOQ), Minnesota, 2010: accessed December 5, 2012, at http://www.mngeo.state.mn.us/chouse/metadata/naip10. html.

U.S. Geological Survey, 2011, Water resources of the United States - 2011 Annual Data Report-Definition of terms: U.S. Geological Survey Water-Data Report WDRUS-2011, accessed November 19, 2012, at http://wdrwater. usgs.gov/wy2011/termDefs.html. 



\section{Glossary}

The following definitions, except where otherwise noted, are from Langbein and Iseri (1960).

annual exceedance probability The probability that a given event magnitude will be exceeded or equaled in any given year. The annual exceedance probability is directly related to the recurrence interval. For example, there is a 1-percent chance that the 100year peak flow will be exceeded or equaled in any given year. A flood probability of 0.01 has a recurrence interval of 100 years. The recurrence interval corresponding to a particular flood probability is equal to one divided by the flood probability (Holmes and Dinicola, 2010).

cold front A zone separating two air masses, of which the cooler, denser mass is advancing and replacing the warmer mass (National Weather Service, 2009).

continuous-record streamgage A site where data are collected with sufficient frequency to define daily mean values and variations within a day.

crest-stage gage A partial-record streamgage that is nonmechanical, nontelemetered, and intended to record only the peak (crest) stream level since the last site visit.

flood peak The highest value of the stage or discharge attained by a flood; thus, peak stage or peak discharge. "Flood crest" has nearly the same meaning, but because it connotes the top of the flood wave, it is properly used only in referring to stage - thus, "crest stage," but not "crest discharge."

flood profile A graph of elevation of the water surface of a river in flood, plotted as ordinate, against distance, measured in the downstream direction, plotted as abscissa. A flood profile may be drawn to show elevation at a given time or crests during a particular flood.

gage height The water-surface elevation referred to some arbitrary gage datum. Gage height is often used interchangeably with the more general term "stage," although gage height is more appropriate when used with a reading on a gage.

high-water mark The highest stage reached by a flood that has been maintained for a sufficient period to leave evidence on the landscape (Benson and Dalrymple, 1967).

recurrence interval (return period) The average interval of time within which the given flood will be equaled or exceeded once. The recurrence interval is directly related to the flood probability. The recurrence interval corresponding to a particular flood probability is equal to 1 divided by the flood probability. For example, a 100-year recurrence interval has a flood probability of 0.01 .

streamflow The discharge in a natural channel. Although the term "discharge" can be applied to the flow of a canal, the word "streamflow" uniquely describes the discharge in a surface stream course.

streamgage A site on a stream, canal, lake, or reservoir where systematic observations of stage, discharge, or other hydrologic data are obtained (U.S. Geological Survey, 2011). In this report, when it is necessary to distinguish between specific types of instrumentation or data used at a streamgage, the following terms are used: "continuous-record streamgage" is used for the sites where continuous-record data are collected, and "crest-stage gage" is used for the sites where partial-record data are collected.

thalweg The area of maximum water velocity within a channel flow (Charlton, 2009).

warm front $A$ transition zone between a mass of warm air and the colder air it is replacing (National Weather Service, 2009). 

Appendix 1. High-Water-Mark Descriptions 
Table 1-1. High-water-mark descriptions for the mapped communities of Barnum, Carlton, Duluth Heights neighborhood in Duluth, Fond du Lac neighborhood in Duluth, Moose Lake, and Thomson for the floods of June 2012 in northeastern Minnesota.

[Vertical coordinate data are referenced to the North American Vertical Datum of 1988 (NAVD 88). Horizontal coordinate data are referenced to the North American Datum of 1983. Approximate quality ratings of high-water marks: Excellent, plus or minus ( \pm ) 0.02 foot; Good, \pm 0.05 foot; Fair, \pm 0.1 foot; and Poor, greater than 0.10 foot (Lumia and others, 1986). ${ }^{\circ}$, degrees; ', minutes; ", seconds; --, not available; USACE, U.S. Army Corps of Engineers; USGS, U.S. Geological Survey]

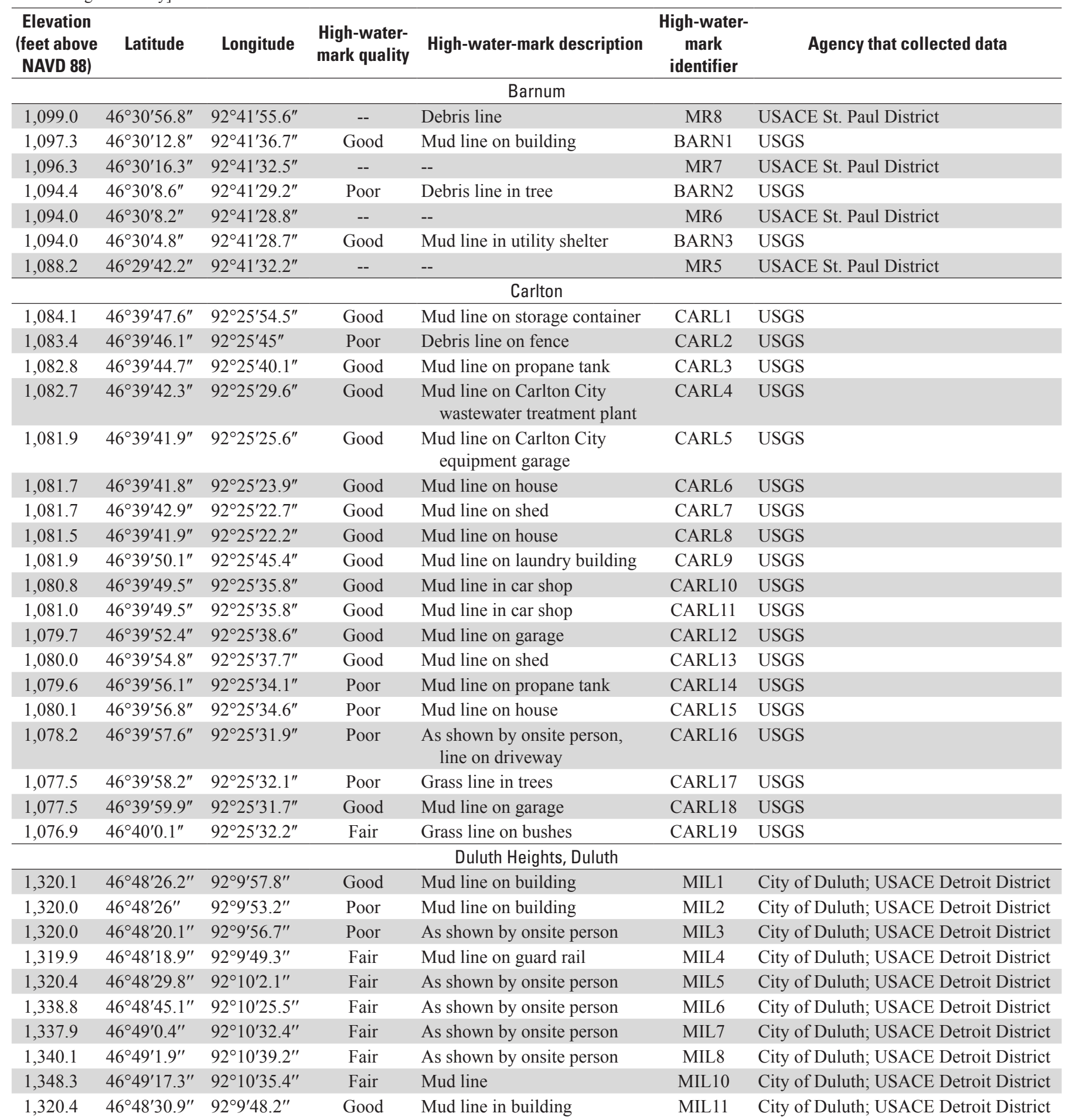


Table 1-1. High-water-mark descriptions for the mapped communities of Barnum, Carlton, Duluth Heights neighborhood in Duluth, Fond du Lac neighborhood in Duluth, Moose Lake, and Thomson for the floods of June 2012 in northeastern Minnesota. - Continued

[Vertical coordinate data are referenced to the North American Vertical Datum of 1988 (NAVD 88). Horizontal coordinate data are referenced to the North American Datum of 1983. Approximate quality ratings of high-water marks: Excellent, plus or minus ( \pm ) 0.02 foot; Good, \pm 0.05 foot; Fair, \pm 0.1 foot; and Poor, greater than 0.10 foot (Lumia and others, 1986). ${ }^{\circ}$, degrees; ', minutes; ", seconds; --, not available; USACE, U.S. Army Corps of Engineers; USGS, U.S. Geological Survey]

\begin{tabular}{|c|c|c|c|c|c|c|}
\hline $\begin{array}{l}\text { Elevation } \\
\text { (feet above } \\
\text { NAVD 88) }\end{array}$ & Latitude & Longitude & $\begin{array}{l}\text { High-water- } \\
\text { mark quality }\end{array}$ & High-water-mark description & $\begin{array}{l}\text { High-water- } \\
\text { mark } \\
\text { identifier }\end{array}$ & Agency that collected data \\
\hline \multicolumn{7}{|c|}{ Fond du Lac, Duluth } \\
\hline 611.6 & $46^{\circ} 39^{\prime} 40.5^{\prime \prime}$ & $92^{\circ} 17^{\prime} 4^{\prime \prime}$ & Fair & $\begin{array}{l}\text { Mud line on power pole next } \\
\text { to river }\end{array}$ & FDL1 & USGS \\
\hline 608.5 & $46^{\circ} 39^{\prime} 39.3^{\prime \prime}$ & $92^{\circ} 16^{\prime} 58.6^{\prime \prime}$ & Poor & Mud line on grass in park & FDL2 & USGS \\
\hline 610.2 & $46^{\circ} 39^{\prime} 35^{\prime \prime}$ & $92^{\circ} 16^{\prime} 41.4^{\prime \prime}$ & Fair & Mud line on red shed & FDL3 & USGS \\
\hline 608.5 & $46^{\circ} 39^{\prime} 35.5^{\prime \prime}$ & $92^{\circ} 16^{\prime} 38.1^{\prime \prime}$ & Fair & Mud line on shed & FDL4 & USGS \\
\hline 607.6 & $46^{\circ} 39^{\prime} 36^{\prime \prime}$ & $92^{\circ} 16^{\prime} 37.1^{\prime \prime}$ & Fair & Grass line on garage & FDL5 & USGS \\
\hline 606.8 & $46^{\circ} 39^{\prime} 33.5^{\prime \prime}$ & $92^{\circ} 16^{\prime} 37.4^{\prime \prime}$ & Fair & Mud line on shed & FDL6 & USGS \\
\hline 607.1 & $46^{\circ} 39^{\prime} 33.8^{\prime \prime}$ & $92^{\circ} 16^{\prime} 36.7^{\prime \prime}$ & Fair & Mud line on shed & FDL7 & USGS \\
\hline 609.2 & $46^{\circ} 39^{\prime} 34.7^{\prime \prime}$ & $92^{\circ} 16^{\prime} 36.3^{\prime \prime}$ & Poor & Grass line on fence & FDL8 & USGS \\
\hline 613.5 & $46^{\circ} 39^{\prime} 40.3^{\prime \prime}$ & $92^{\circ} 16^{\prime} 26.6^{\prime \prime}$ & Poor & Grass line on fence & FDL9 & USGS \\
\hline 609.3 & $46^{\circ} 39^{\prime} 25.4^{\prime \prime}$ & $92^{\circ} 16^{\prime} 22.1^{\prime \prime}$ & Good & Mud line on house & FDL10 & USGS \\
\hline 609.5 & $46^{\circ} 39^{\prime} 16.7^{\prime \prime}$ & $92^{\circ} 16^{\prime} 22.3^{\prime \prime}$ & Good & Seed line on shed & FDL11 & USGS \\
\hline 609.3 & $46^{\circ} 39^{\prime} 16.4^{\prime \prime}$ & $92^{\circ} 16^{\prime} 22.1^{\prime \prime}$ & Fair & Grass line on fence & FDL12 & USGS \\
\hline 608.9 & $46^{\circ} 39^{\prime} 16.1^{\prime \prime}$ & $92^{\circ} 16^{\prime} 22.1^{\prime \prime}$ & Fair & Mud line on house & FDL13 & USGS \\
\hline 608.7 & $46^{\circ} 39^{\prime} 5.6^{\prime \prime}$ & $92^{\circ} 16^{\prime} 14.4^{\prime \prime}$ & Good & Grass line on house & FDL14 & USGS \\
\hline \multicolumn{7}{|c|}{ Moose Lake } \\
\hline $1,052.5$ & $46^{\circ} 27^{\prime} 27.4^{\prime \prime}$ & $92^{\circ} 45^{\prime} 4.4^{\prime \prime}$ & -- & -- & MR3 & USACE St. Paul District \\
\hline $1,048.2$ & $46^{\circ} 27^{\prime} 6.2^{\prime \prime}$ & $92^{\circ} 44^{\prime} 46.4^{\prime \prime}$ & Good & Mud line on paved trail & MOOSE1 & USGS \\
\hline $1,049.2$ & $46^{\circ} 27^{\prime} 4.4^{\prime \prime}$ & $92^{\circ} 44^{\prime} 46.3^{\prime \prime}$ & Fair & Mud line on paved trail & MOOSE2 & USGS \\
\hline $1,053.3$ & $46^{\circ} 27^{\prime} 23.2^{\prime \prime}$ & $92^{\circ} 45^{\prime} 24.3^{\prime \prime}$ & Poor & Debris line in tree & MOOSE3 & USGS \\
\hline $1,052.8$ & $46^{\circ} 27^{\prime} 2.4^{\prime \prime}$ & $92^{\circ} 45^{\prime} 34.7^{\prime \prime}$ & Good & Mud line on building & MOOSE4 & USGS \\
\hline $1,052.5$ & $46^{\circ} 26^{\prime} 30^{\prime \prime}$ & $92^{\circ} 45^{\prime} 40.9^{\prime \prime}$ & Good & Debris line on ground & MOOSE5 & USGS \\
\hline $1,052.9$ & $46^{\circ} 26^{\prime} 46.2^{\prime \prime}$ & $92^{\circ} 46^{\prime} 6.9^{\prime \prime}$ & Fair & Scratch mark on bridge rail & MOOSE6 & USGS \\
\hline $1,052.9$ & $46^{\circ} 26^{\prime} 46.2^{\prime \prime}$ & $92^{\circ} 46^{\prime} 6.9^{\prime \prime}$ & Fair & Scratch mark on bridge rail & MOOSE7 & USGS \\
\hline $1,052.1$ & $46^{\circ} 26^{\prime} 45.7^{\prime \prime}$ & $92^{\circ} 46^{\prime} 7.3^{\prime \prime}$ & -- & -- & MR2 & USACE St. Paul District \\
\hline $1,050.8$ & $46^{\circ} 26^{\prime} 50.3^{\prime \prime}$ & $92^{\circ} 46^{\prime} 17.2^{\prime \prime}$ & Good & Mud line on building & MOOSE8 & USGS \\
\hline $1,042.9$ & $46^{\circ} 26^{\prime} 38.7^{\prime \prime}$ & $92^{\circ} 46^{\prime} 34.4^{\prime \prime}$ & Poor & Debris line on ground & MOOSE9 & USGS \\
\hline \multicolumn{7}{|c|}{ Thomson } \\
\hline $1,054.9$ & $46^{\circ} 39^{\prime} 49.7^{\prime \prime}$ & $92^{\circ} 23^{\prime} 27.7^{\prime \prime}$ & Good & Mud line on garage & ETHOM1 & USGS \\
\hline $1,054.9$ & $46^{\circ} 39^{\prime} 47.9^{\prime \prime}$ & $92^{\circ} 23^{\prime} 26.8^{\prime \prime}$ & Good & Mud line on house & ETHOM2 & USGS \\
\hline $1,072.0$ & $46^{\circ} 39^{\prime} 59.9^{\prime \prime}$ & $92^{\circ} 23^{\prime} 56.6^{\prime \prime}$ & Poor & Seed/Grass line on tree & THOM1 & USGS \\
\hline $1,071.0$ & $46^{\circ} 39^{\prime} 59.7^{\prime \prime}$ & $92^{\circ} 23^{\prime} 57.1^{\prime \prime}$ & Poor & Seed/Grass line in tree & THOM2 & USGS \\
\hline $1,064.9$ & $46^{\circ} 39^{\prime} 58.5^{\prime \prime}$ & $92^{\circ} 23^{\prime} 59.8^{\prime \prime}$ & Poor & Mud line behind studio & THOM3 & USGS \\
\hline $1,063.0$ & $46^{\circ} 39^{\prime} 58.4^{\prime \prime}$ & $92^{\circ} 23^{\prime} 59^{\prime \prime}$ & Poor & Mud line on front of studio & THOM4 & USGS \\
\hline $1,062.6$ & $46^{\circ} 39^{\prime} 58.1^{\prime \prime}$ & $92^{\circ} 23^{\prime} 59.8^{\prime \prime}$ & Poor & Debris line in grass & THOM5 & USGS \\
\hline $1,061.5$ & $46^{\circ} 39^{\prime} 57.4^{\prime \prime}$ & $92^{\circ} 23^{\prime} 56.5^{\prime \prime}$ & Poor & $\begin{array}{l}\text { As shown by onsite person, on } \\
\text { step next to brick planter }\end{array}$ & THOM6 & USGS \\
\hline $1,050.5$ & $46^{\circ} 39^{\prime} 54.6^{\prime \prime}$ & $92^{\circ} 23^{\prime} 57.7^{\prime \prime}$ & Poor & Debris caught in fence & THOM7 & USGS \\
\hline $1,047.2$ & $46^{\circ} 39^{\prime} 52.6^{\prime \prime}$ & $92^{\circ} 23^{\prime} 57.4^{\prime \prime}$ & Poor & Debris line in tree & THOM8 & USGS \\
\hline $1,048.6$ & $46^{\circ} 39^{\prime} 52^{\prime \prime}$ & $92^{\circ} 23^{\prime} 56.6^{\prime \prime}$ & Fair & Debris line in power pole & THOM9 & USGS \\
\hline $1,046.9$ & $46^{\circ} 39^{\prime} 52.3^{\prime \prime}$ & $92^{\circ} 24^{\prime} 0.1^{\prime \prime}$ & Poor & Debris line at base of stake & THOM10 & USGS \\
\hline $1,046.1$ & $46^{\circ} 39^{\prime} 48.9^{\prime \prime}$ & $92^{\circ} 23^{\prime} 57.6^{\prime \prime}$ & Good & Mud line on pump house & THOM11 & USGS \\
\hline $1,036.0$ & $46^{\circ} 39^{\prime} 47.4^{\prime \prime}$ & $92^{\circ} 24^{\prime} 0.4^{\prime \prime}$ & Poor & $\begin{array}{l}\text { Debris at culvert under bike } \\
\text { path }\end{array}$ & THOM12 & USGS \\
\hline $1,041.1$ & $46^{\circ} 39^{\prime} 47.2^{\prime \prime}$ & $92^{\circ} 23^{\prime} 59.8^{\prime \prime}$ & Poor & Debris line in trees & THOM13 & USGS \\
\hline
\end{tabular}


Table 1-2. Descriptions of additional high-water marks for the floods of June 2012 in northeastern Minnesota.

[Vertical coordinate data are referenced to the North American Vertical Datum of 1988 (NAVD 88). Horizontal coordinate data are referenced to the North American Datum of 1983. Approximate quality ratings of high-water marks: Excellent, \pm 0.02 foot; Good, \pm 0.05 foot; Fair, \pm 0.1 foot; and Poor, greater than 0.10 foot (Lumia and others, 1986). ${ }^{\circ}$, degrees; ', minutes; ", seconds; USACE, U.S. Army Corps of Engineers; --, not available]

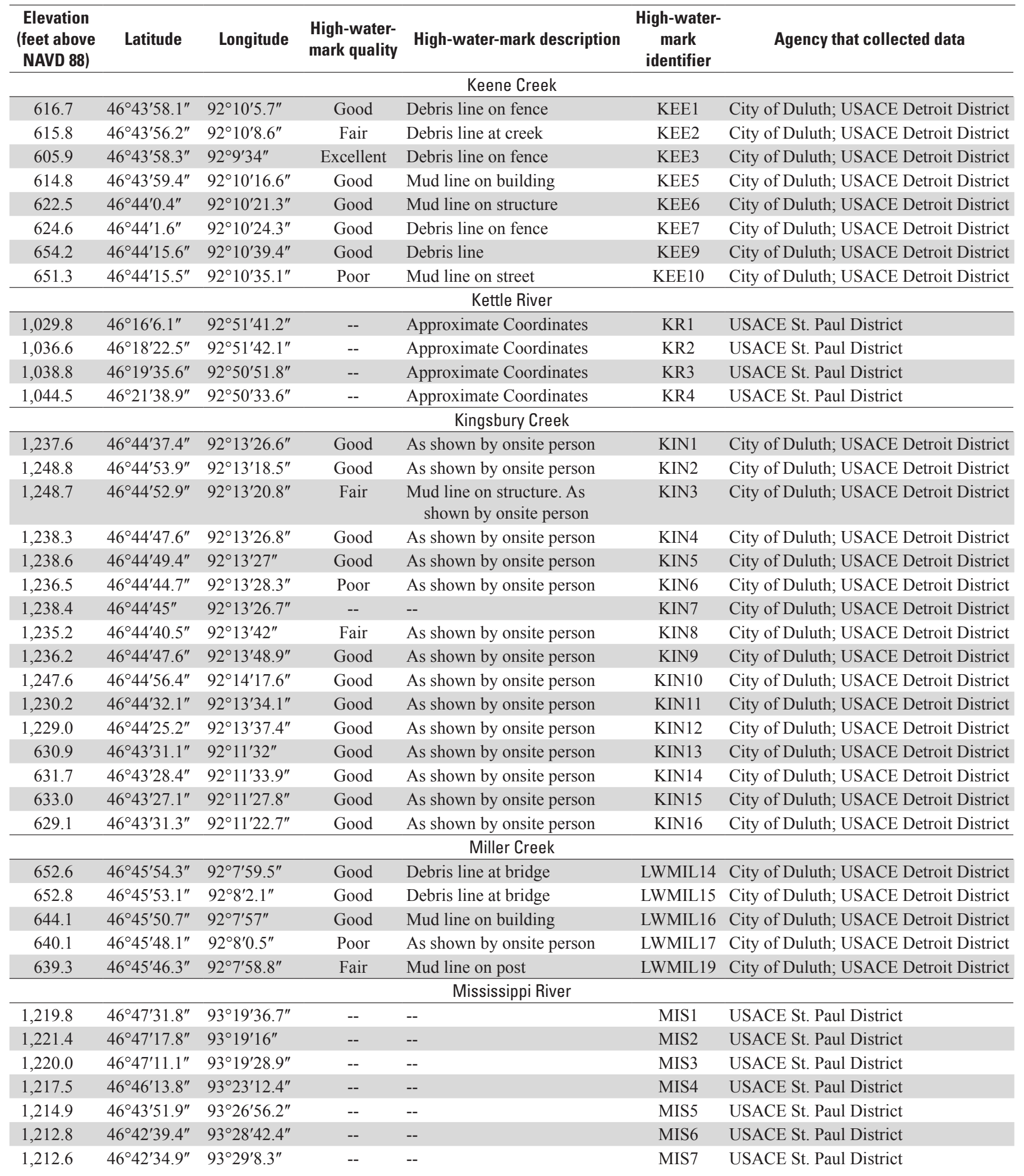


Table 1-2. Descriptions of additional high-water marks for the floods of June 2012 in northeastern Minnesota.—Continued

[Vertical coordinate data are referenced to the North American Vertical Datum of 1988 (NAVD 88). Horizontal coordinate data are referenced to the North American Datum of 1983. Approximate quality ratings of high-water marks: Excellent, \pm 0.02 foot; Good, \pm 0.05 foot; Fair, \pm 0.1 foot; and Poor, greater than 0.10 foot (Lumia and others, 1986). , degrees; ', minutes; ", seconds; USACE, U.S. Army Corps of Engineers; --, not available]

\begin{tabular}{|c|c|c|c|c|c|c|}
\hline $\begin{array}{c}\text { Elevation } \\
\text { (feet above } \\
\text { NAVD 88) } \\
\end{array}$ & Latitude & Longitude & $\begin{array}{l}\text { High-water- } \\
\text { mark quality }\end{array}$ & High-water-mark description & $\begin{array}{l}\text { High-water- } \\
\text { mark } \\
\text { identifier }\end{array}$ & Agency that collected data \\
\hline \multicolumn{7}{|c|}{ Mississippi River-Continued } \\
\hline $1,209.7$ & $46^{\circ} 40^{\prime} 41.5^{\prime \prime}$ & $93^{\circ} 36^{\prime} 2.8^{\prime \prime}$ & -- & $\begin{array}{l}\text { Overland flow crossing road } \\
\text { probably from Willow River }\end{array}$ & MIS9 & USACE St. Paul District \\
\hline $1,205.8$ & $46^{\circ} 37^{\prime} 30.5^{\prime \prime}$ & $93^{\circ} 38^{\prime} 45.5^{\prime \prime}$ & -- & -- & MIS12 & USACE St. Paul District \\
\hline $1,203.3$ & $46^{\circ} 35^{\prime} 23.5^{\prime \prime}$ & $93^{\circ} 39^{\prime} 53.6^{\prime \prime}$ & -- & -- & MIS13 & USACE St. Paul District \\
\hline $1,202.1$ & $46^{\circ} 33^{\prime} 42.6^{\prime \prime}$ & $93^{\circ} 41^{\prime} 47.3^{\prime \prime}$ & -- & Flood debris / silt line on tree & MIS14 & USACE St. Paul District \\
\hline $1,202.1$ & $46^{\circ} 34^{\prime} 46.8^{\prime \prime}$ & $93^{\circ} 42^{\prime} 25.4^{\prime \prime}$ & -- & -- & MIS15 & USACE St. Paul District \\
\hline $1,200.6$ & $46^{\circ} 32^{\prime} 47.8^{\prime \prime}$ & $93^{\circ} 42^{\prime} 26.5^{\prime \prime}$ & -- & -- & MIS16 & USACE St. Paul District \\
\hline $1,200.1$ & $46^{\circ} 32^{\prime} 51^{\prime \prime}$ & $93^{\circ} 46^{\prime} 32.6^{\prime \prime}$ & -- & -- & MIS20 & USACE St. Paul District \\
\hline $1,199.1$ & $46^{\circ} 34^{\prime} 44.1^{\prime \prime}$ & $93^{\circ} 47^{\prime} 31.2^{\prime \prime}$ & -- & $\begin{array}{l}\text { Debris line, edge of field, right } \\
\text { side of house past electric } \\
\text { fence }\end{array}$ & MIS21 & USACE St. Paul District \\
\hline $1,199.3$ & $46^{\circ} 35^{\prime} 3.3^{\prime \prime}$ & $93^{\circ} 48^{\prime} 6.9^{\prime \prime}$ & -- & -- & MIS22 & USACE St. Paul District \\
\hline $1,199.0$ & $46^{\circ} 35^{\prime} 6.6^{\prime \prime}$ & $93^{\circ} 48^{\prime} 55.9^{\prime \prime}$ & -- & -- & MIS23 & USACE St. Paul District \\
\hline $1,197.1$ & $46^{\circ} 34^{\prime} 13.8^{\prime \prime}$ & $93^{\circ} 52^{\prime} 25.4^{\prime \prime}$ & -- & -- & MIS25 & USACE St. Paul District \\
\hline $1,193.0$ & $46^{\circ} 32^{\prime} 38.5^{\prime \prime}$ & $93^{\circ} 57^{\prime} 20.3^{\prime \prime}$ & -- & -- & MIS26 & USACE St. Paul District \\
\hline \multicolumn{7}{|c|}{ Mississippi River Diversion Channel } \\
\hline $1,202.6$ & $46^{\circ} 35^{\prime} 23.5^{\prime \prime}$ & $93^{\circ} 39^{\prime} 53.6^{\prime \prime}$ & -- & -- & $\mathrm{DC} 1$ & USACE St. Paul District \\
\hline $1,203.0$ & $46^{\circ} 35^{\prime} 23.5^{\prime \prime}$ & $93^{\circ} 39^{\prime} 53.6^{\prime \prime}$ & -- & -- & DC2 & USACE St. Paul District \\
\hline $1,113.4$ & $46^{\circ} 31^{\prime} 10.3^{\prime \prime}$ & $92^{\circ} 42^{\prime} 34.3^{\prime \prime}$ & -- & -- & MR9 & USACE St. Paul District \\
\hline $1,147.7$ & $46^{\circ} 31^{\prime} 9.9^{\prime \prime}$ & $92^{\circ} 43^{\prime} 43^{\prime \prime}$ & -- & -- & MR10 & USACE St. Paul District \\
\hline \multicolumn{7}{|c|}{ Pine River } \\
\hline $1,028.5$ & $46^{\circ} 15^{\prime} 17.1^{\prime \prime}$ & $92^{\circ} 51^{\prime} 58.3^{\prime \prime}$ & -- & Approximate coordinates & PR1 & USACE St. Paul District \\
\hline $1,033.4$ & $46^{\circ} 15^{\prime} 34.3^{\prime \prime}$ & $92^{\circ} 53^{\prime} 37.8^{\prime \prime}$ & -- & Approximate coordinates & PR2 & USACE St. Paul District \\
\hline $1,043.1$ & $46^{\circ} 16^{\prime} 22.1^{\prime \prime}$ & $92^{\circ} 54^{\prime} 28.1^{\prime \prime}$ & -- & Approximate coordinates & PR3 & USACE St. Paul District \\
\hline $1,071.6$ & $46^{\circ} 18^{\prime} 12.7^{\prime \prime}$ & $92^{\circ} 54^{\prime} 28.7^{\prime \prime}$ & -- & Approximate coordinates & PR4 & USACE St. Paul District \\
\hline $1,072.7$ & $46^{\circ} 18^{\prime} 36.6^{\prime \prime}$ & $92^{\circ} 54^{\prime} 28.2^{\prime \prime}$ & -- & $\begin{array}{l}\text { Approximate coordinates. } \\
\text { Water on road }\end{array}$ & PR5 & USACE St. Paul District \\
\hline \multicolumn{7}{|c|}{ Willow River } \\
\hline $1,038.5$ & $46^{\circ} 19^{\prime} 24.9^{\prime \prime}$ & $92^{\circ} 50^{\prime} 21.5^{\prime \prime}$ & -- & Approximate coordinates & WR1 & USACE St. Paul District \\
\hline
\end{tabular}



Appendix 2. Flood-Peak Inundation Maps 
$92^{\circ} 43^{\prime}$

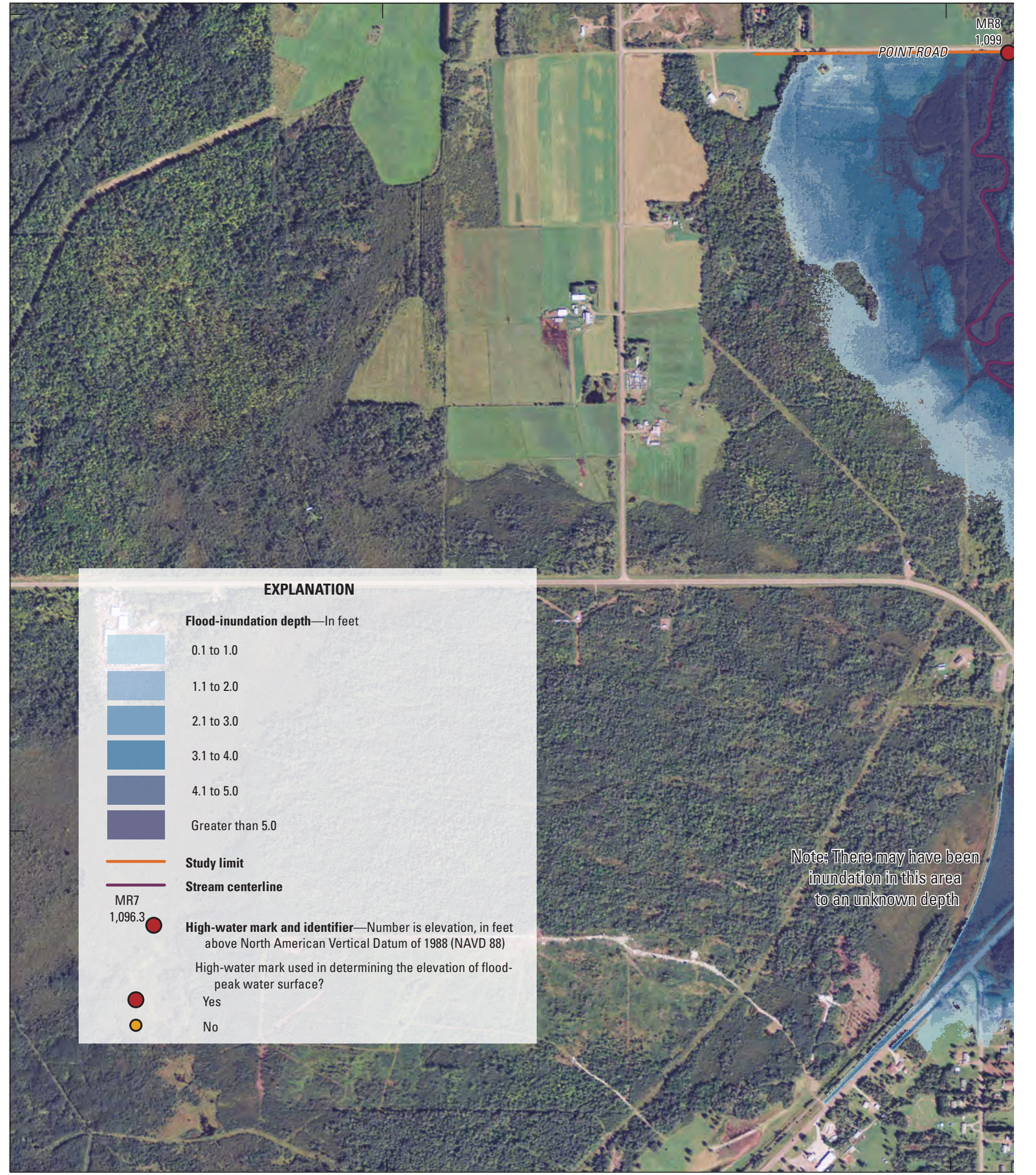

Aerial photograph courtesy of MNGEO, Spatial Data Portal, 2010 National Agriculture Imagery Program, accessed December 2012, at http://www.mngeo.state.mn.us/chouse/metadata/naip10.htm/ Universal Transverse Mercator projection, Zone 15

Figure 2-1. Approximate extent and depth of flood-peak inundation, flood of June 2012, for the Moose Horn River at Barnum, Minnesota. 
$92^{\circ} 41^{\prime}$

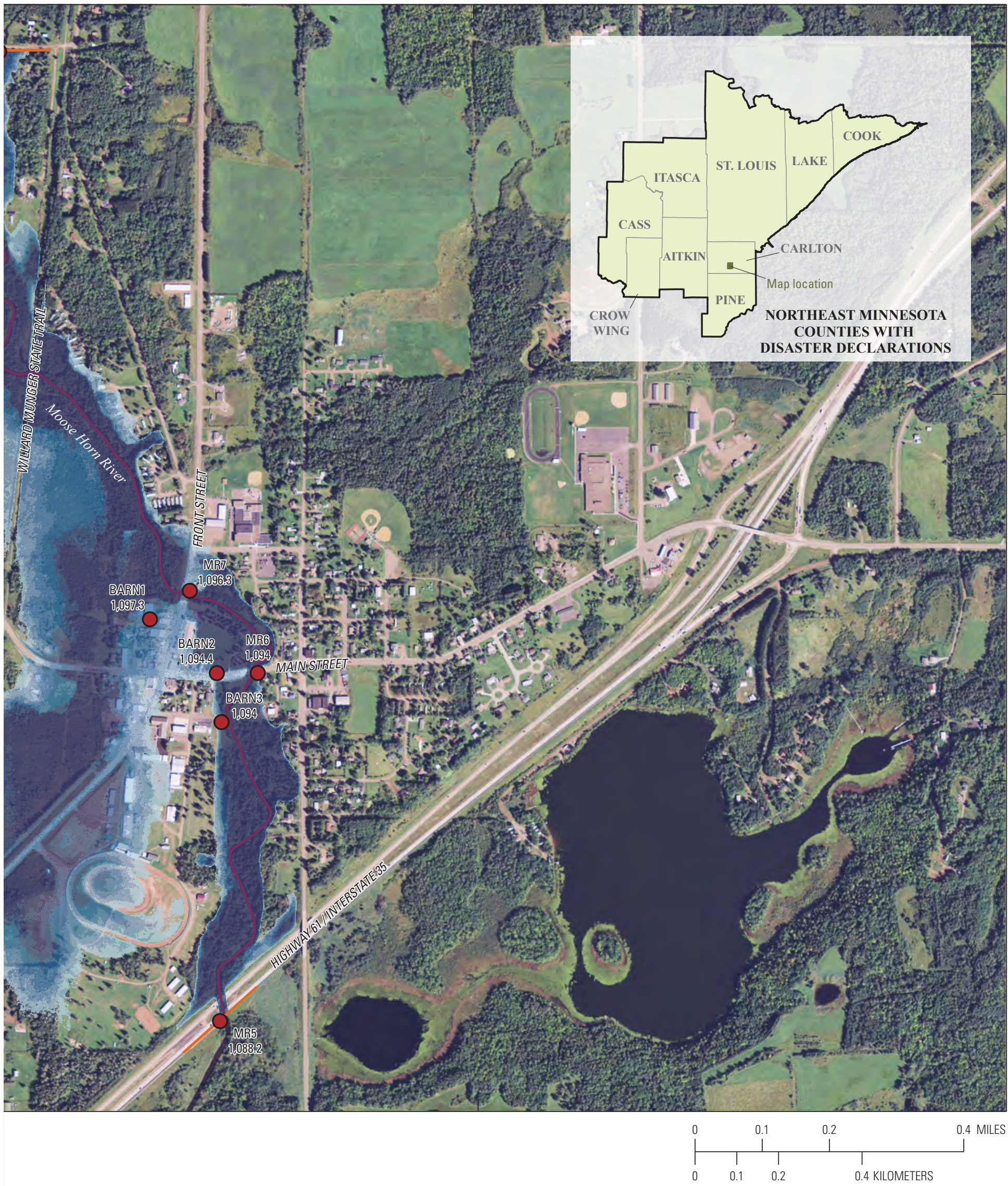




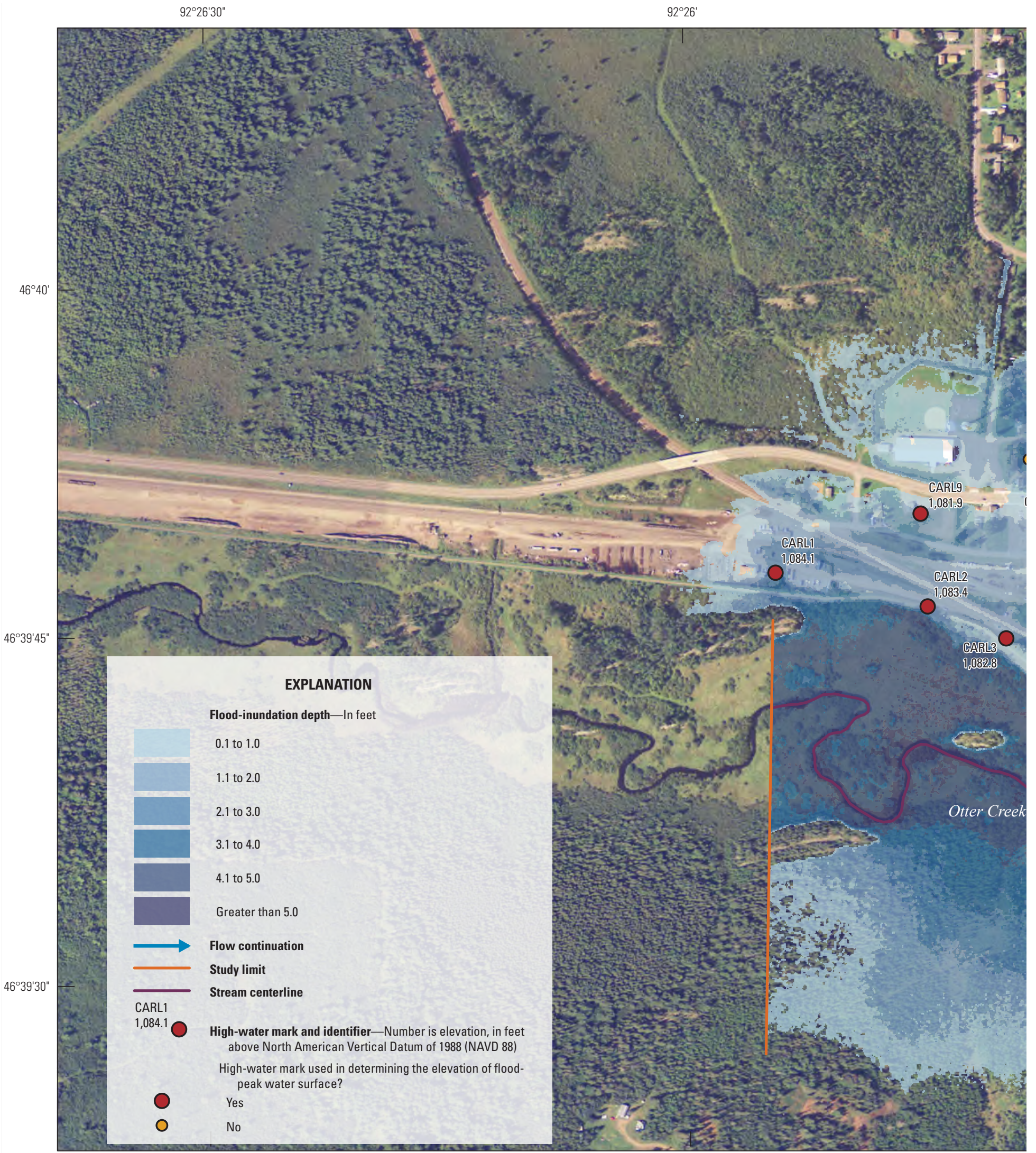

Aerial photograph courtesy of MNGEO, Spatial Data Portal, 2010 National Agriculture Imagery Program, accessed December 2012, at http://www.mngeo.state.mn.us/chouse/metadata/naip10.html Universal Transverse Mercator projection, Zone 15

Figure 2-2. Approximate extent and depth of flood-peak inundation, flood of June 2012, for Otter Creek at Carlton, Minnesota. 


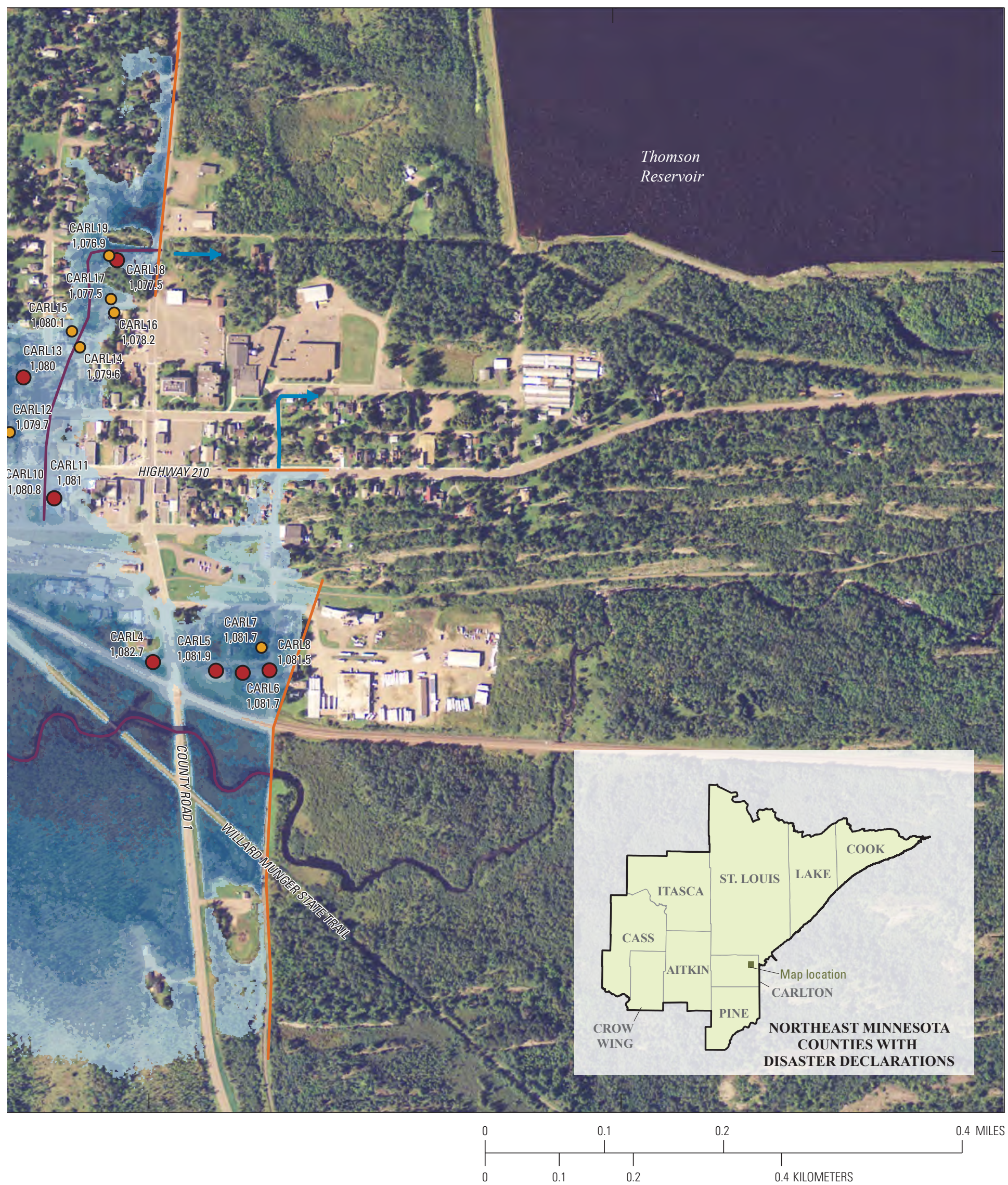




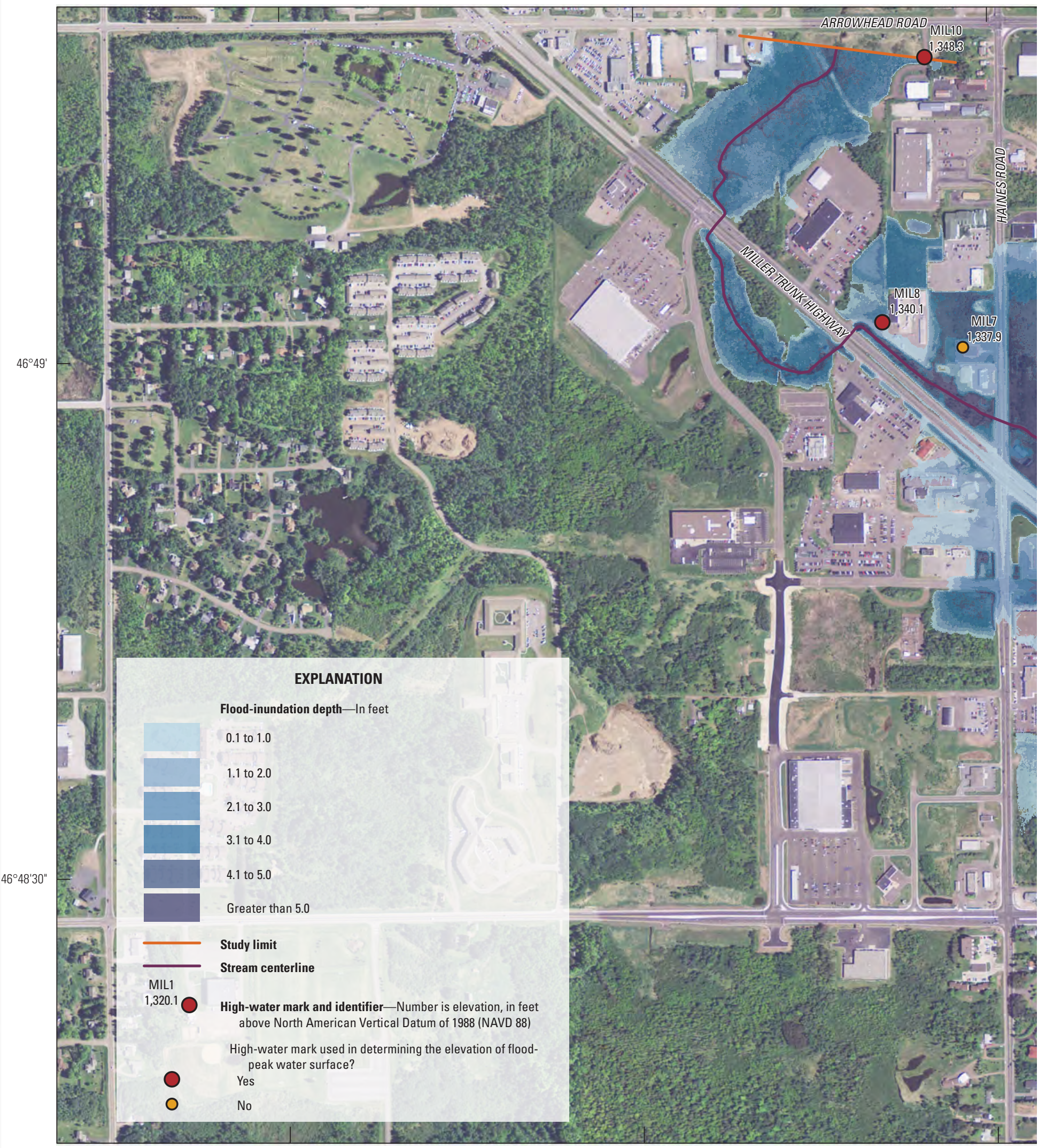

Aerial photograph courtesy of MNGEO, Spatial Data Portal, 2010 National Agriculture Imagery Program, accessed December 2012, at http://www.mngeo.state.mn.us/chouse/metadata/naip10.htm/

Universal Transverse Mercator projection, Zone 15

Figure 2-3. Approximate extent and depth of flood-peak inundation, flood of June 2012, for Miller Creek at the Duluth Heights neighborhood, Duluth, Minnesota. 

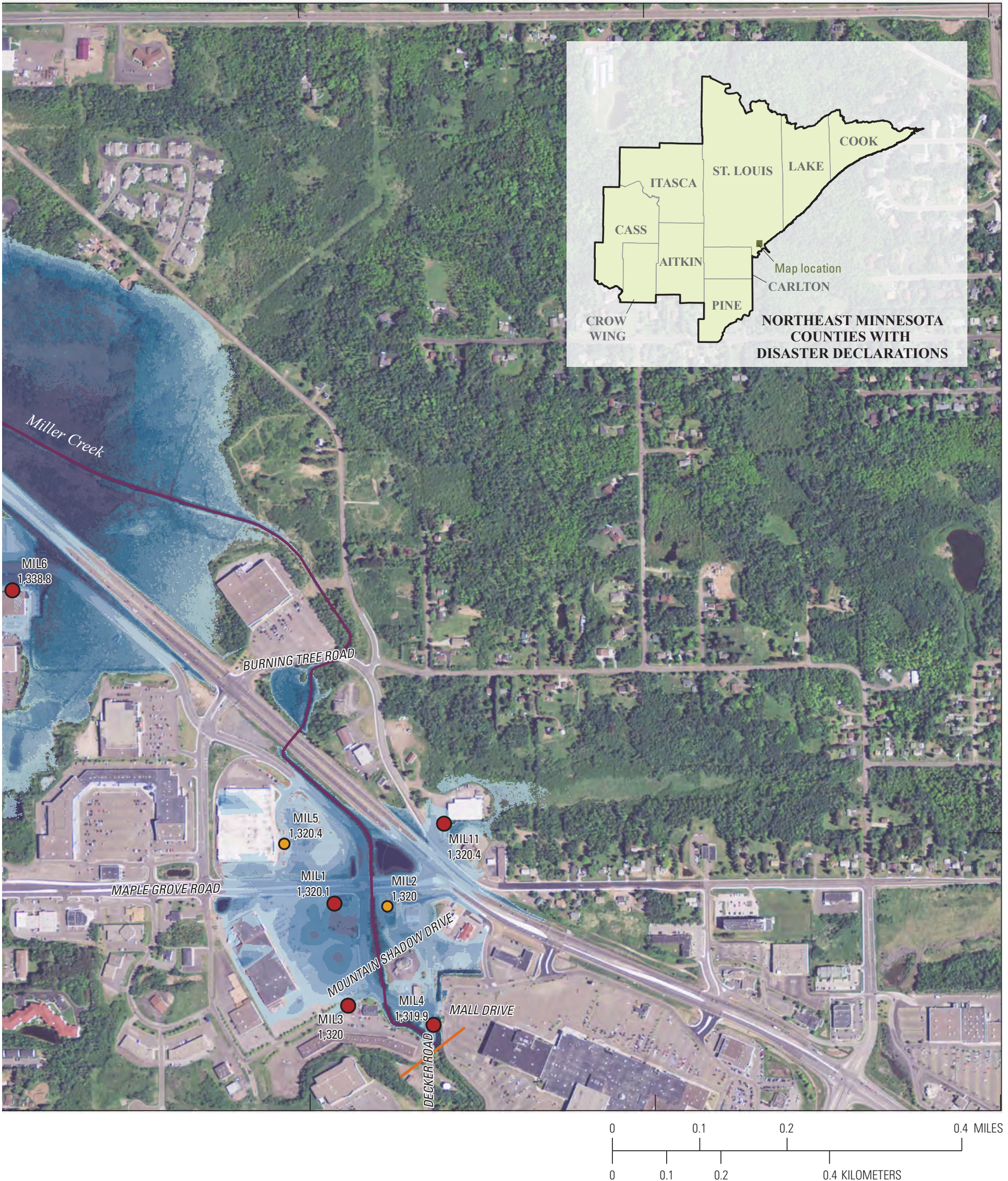


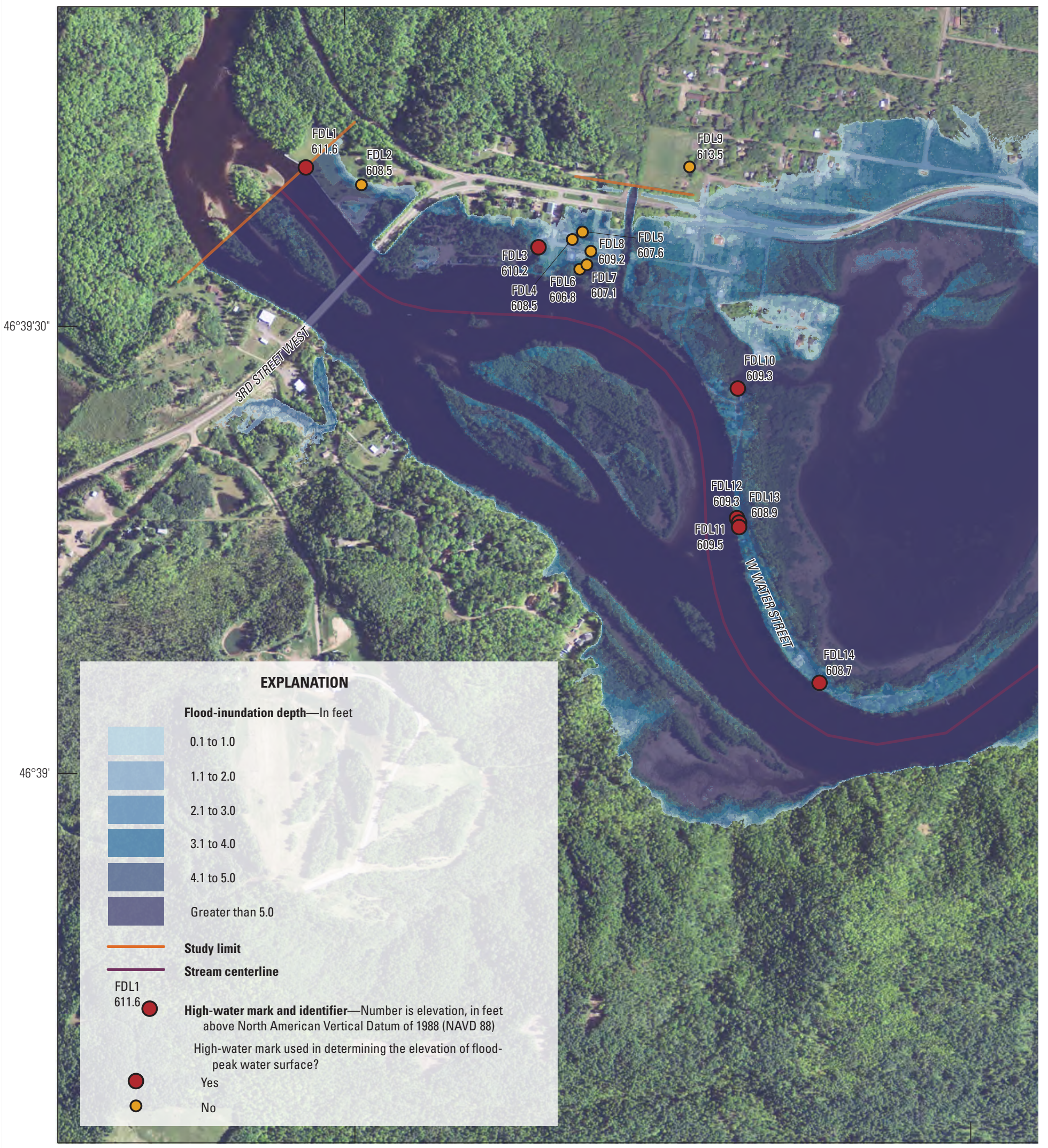

Aerial photograph courtesy of MNGEO, Spatial Data Portal, 2010 National Agriculture Imagery Program, accessed December 2012, at http://www.mngeo.state.mn.us/chouse/metadata/naip10.htm/ Universal Transverse Mercator projection, Zone 15

Figure 2-4. Approximate extent and depth of flood-peak inundation, flood of June 2012, for the St. Louis River at the Fond du Lac neighborhood, Duluth, Minnesota. 
$92^{\circ} 15^{\prime}$

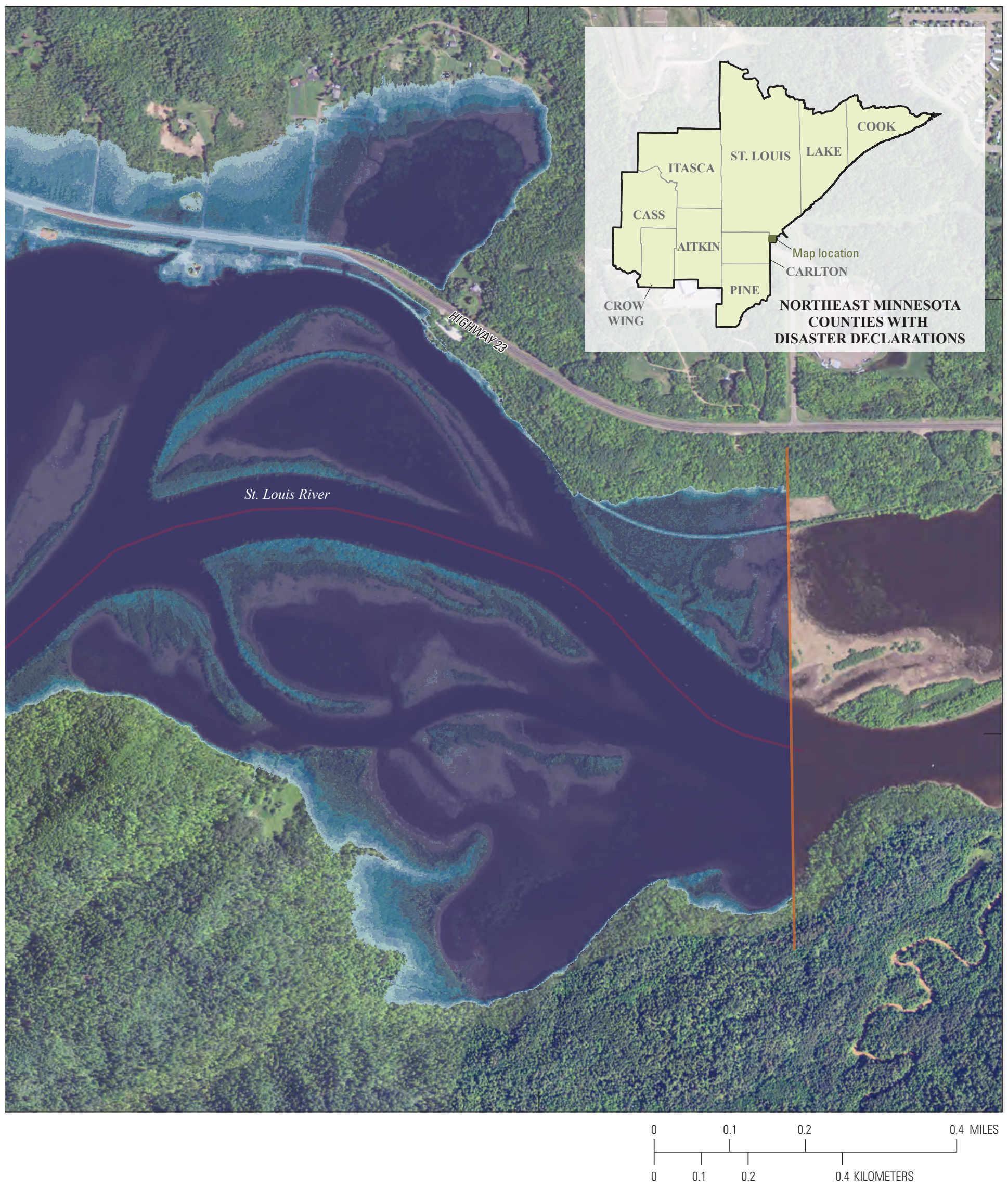




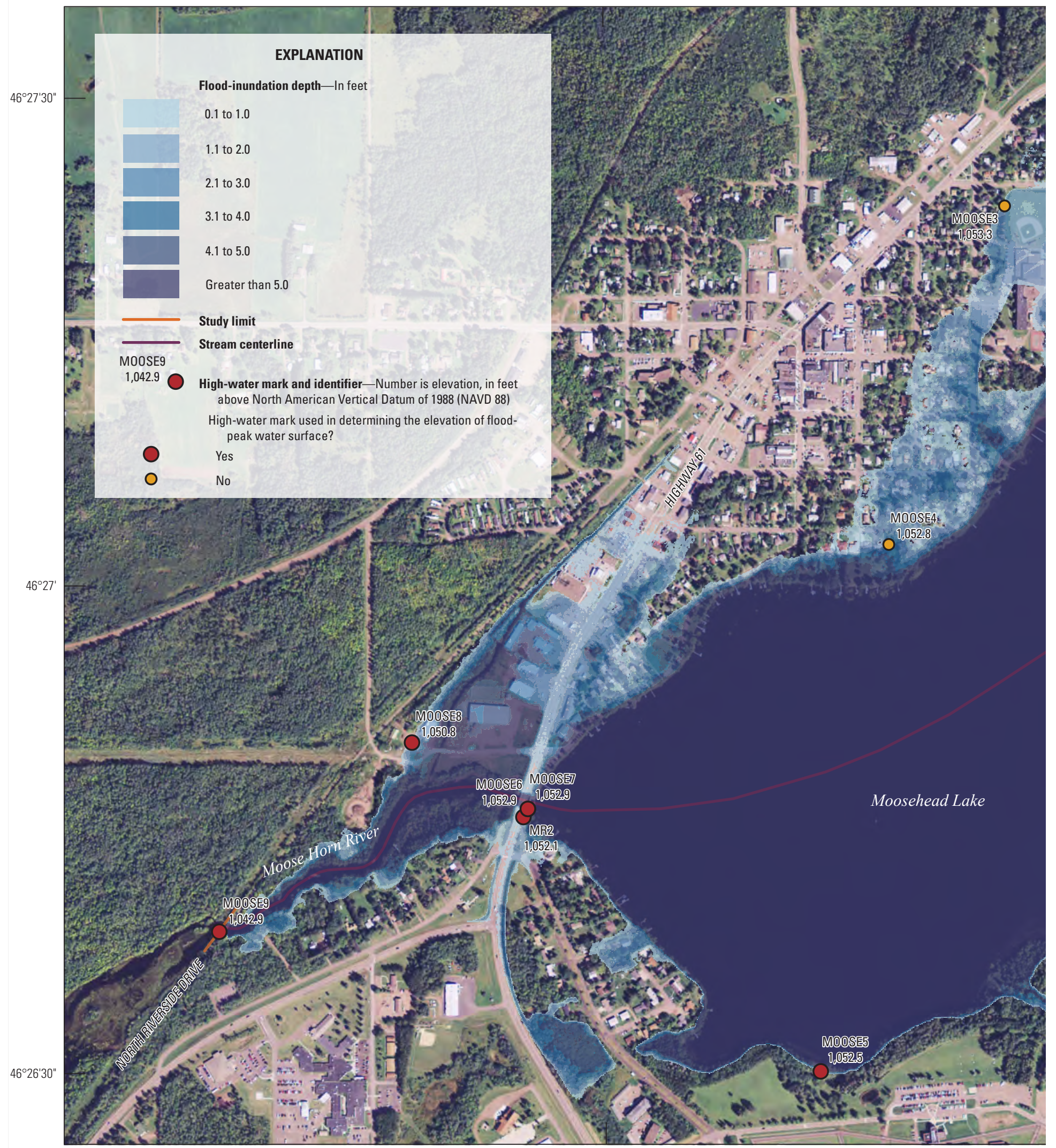

Aerial photograph courtesy of MNGEO, Spatial Data Portal, 2010 National Agriculture Imagery Program, accessed December 2012, at http://www.mngeo.state.mn.us/chouse/metadata/naip10.htm/ Universal Transverse Mercator projection, Zone 15

Figure 2-5. Approximate extent and depth of flood-peak inundation, flood of June 2012, for the Moose Horn River and Moosehead Lake at Moose Lake, Minnesota. 

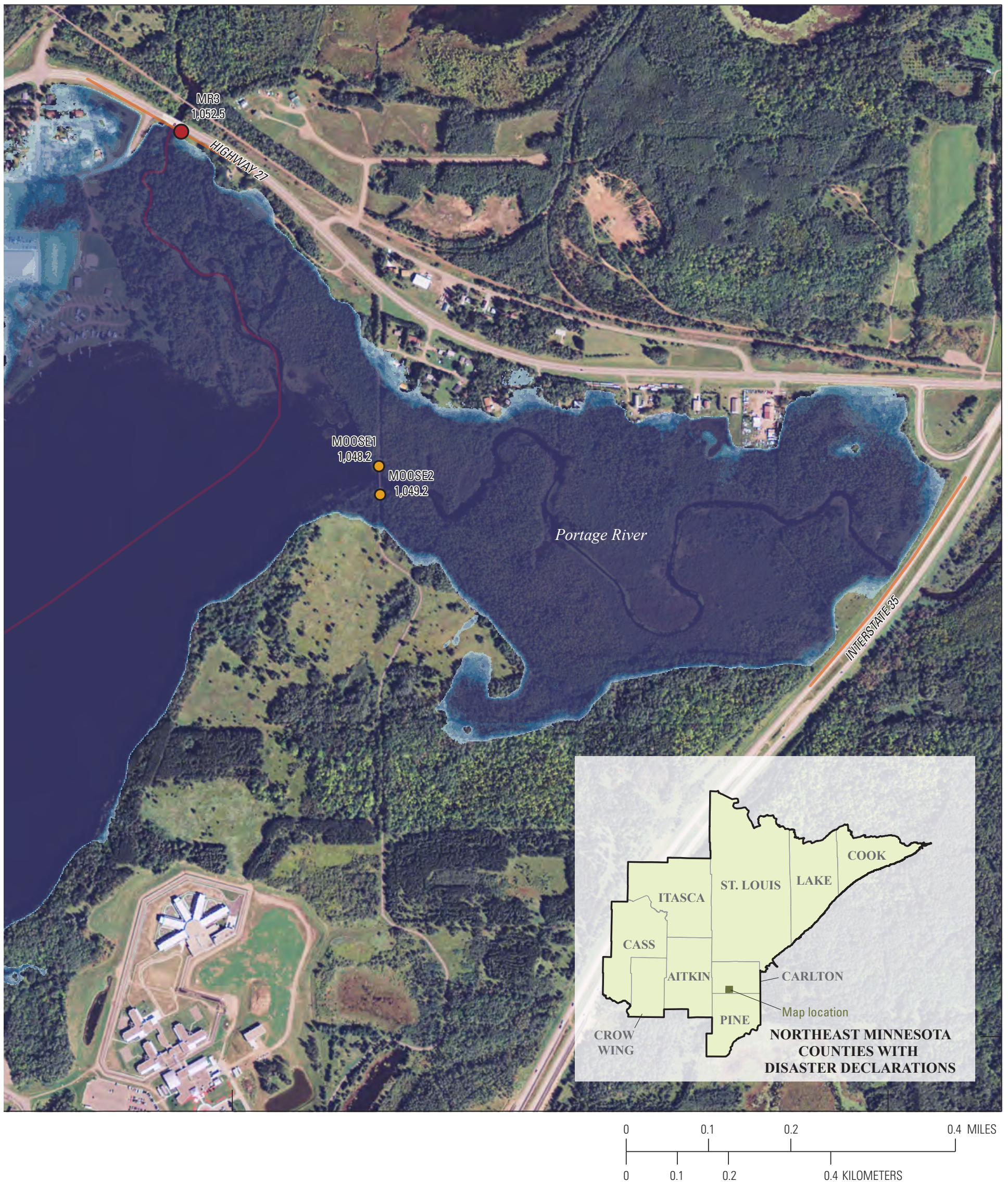


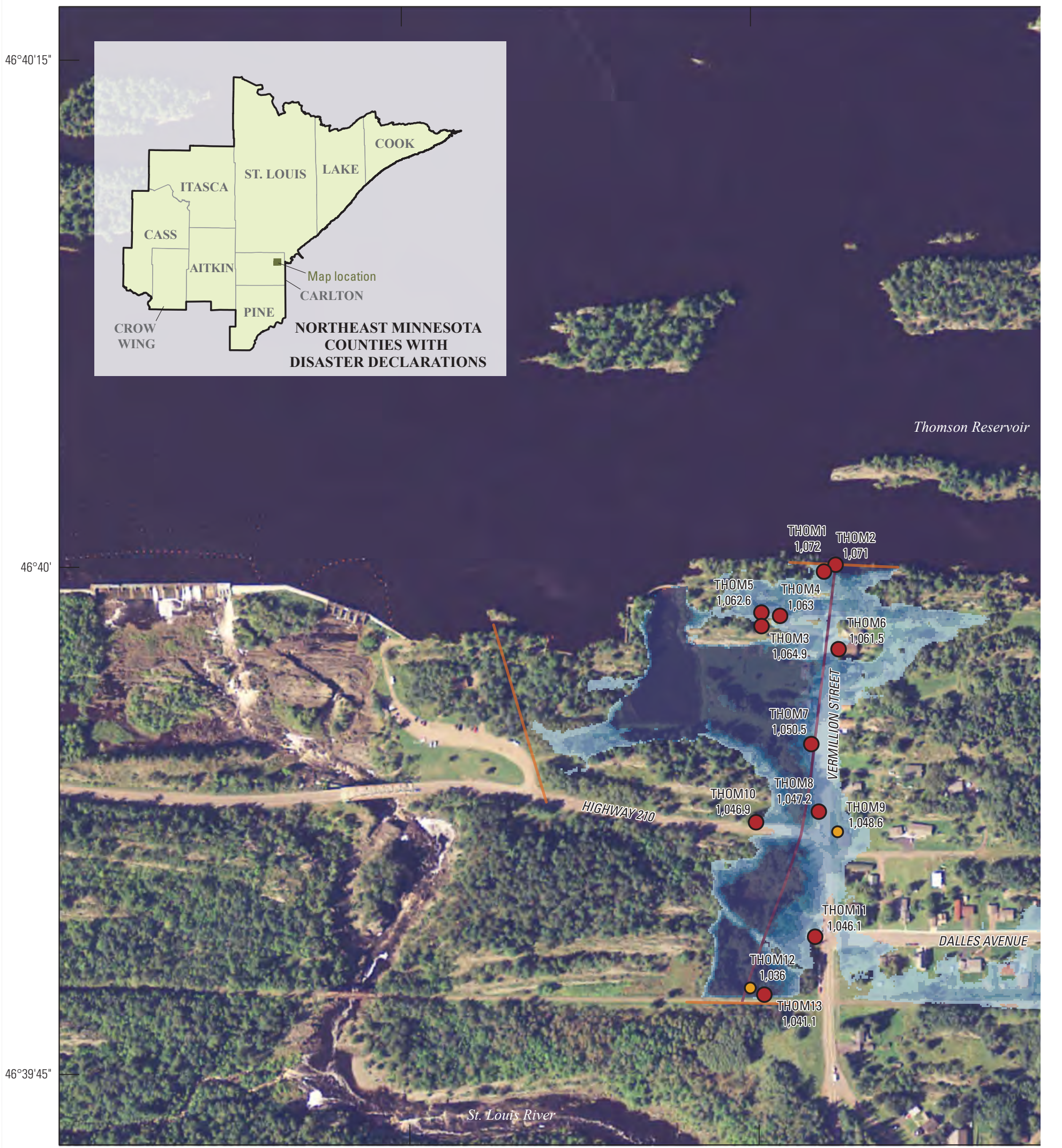

Aerial photograph courtesy of MNGEO, Spatial Data Portal, 2010 National Agriculture Imagery Program, accessed December 2012, at http://www.mngeo.state.mn.us/chouse/metadata/naip10.html

Universal Transverse Mercator projection, Zone 15

Figure 2-6. Approximate extent and depth of flood-peak inundation, flood of June 2012, for the Thomson Reservoir outflow near the St. Louis River at Thomson, Minnesota. 

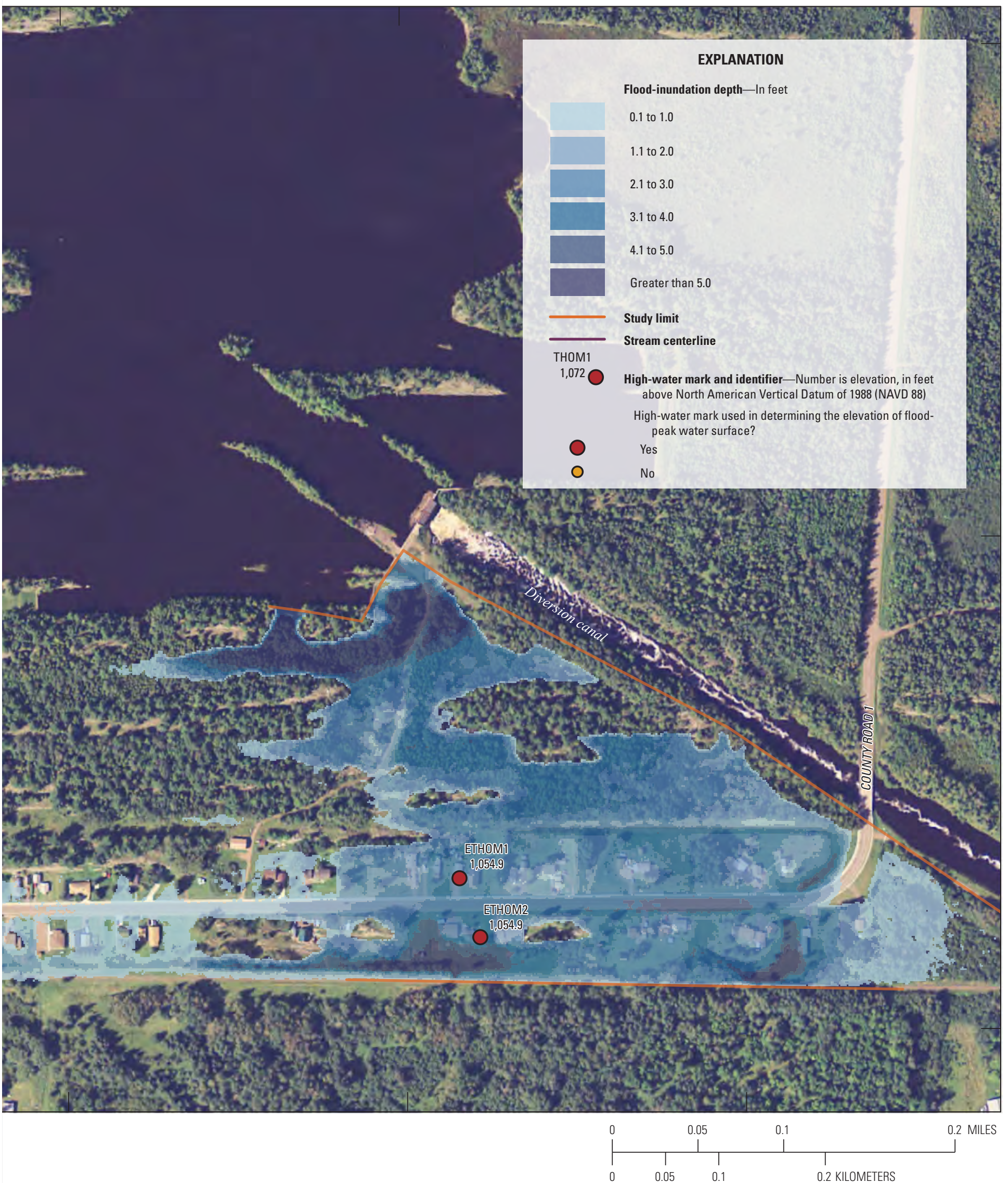

Appendix 3. Flood-Peak Water-Surface Profiles 


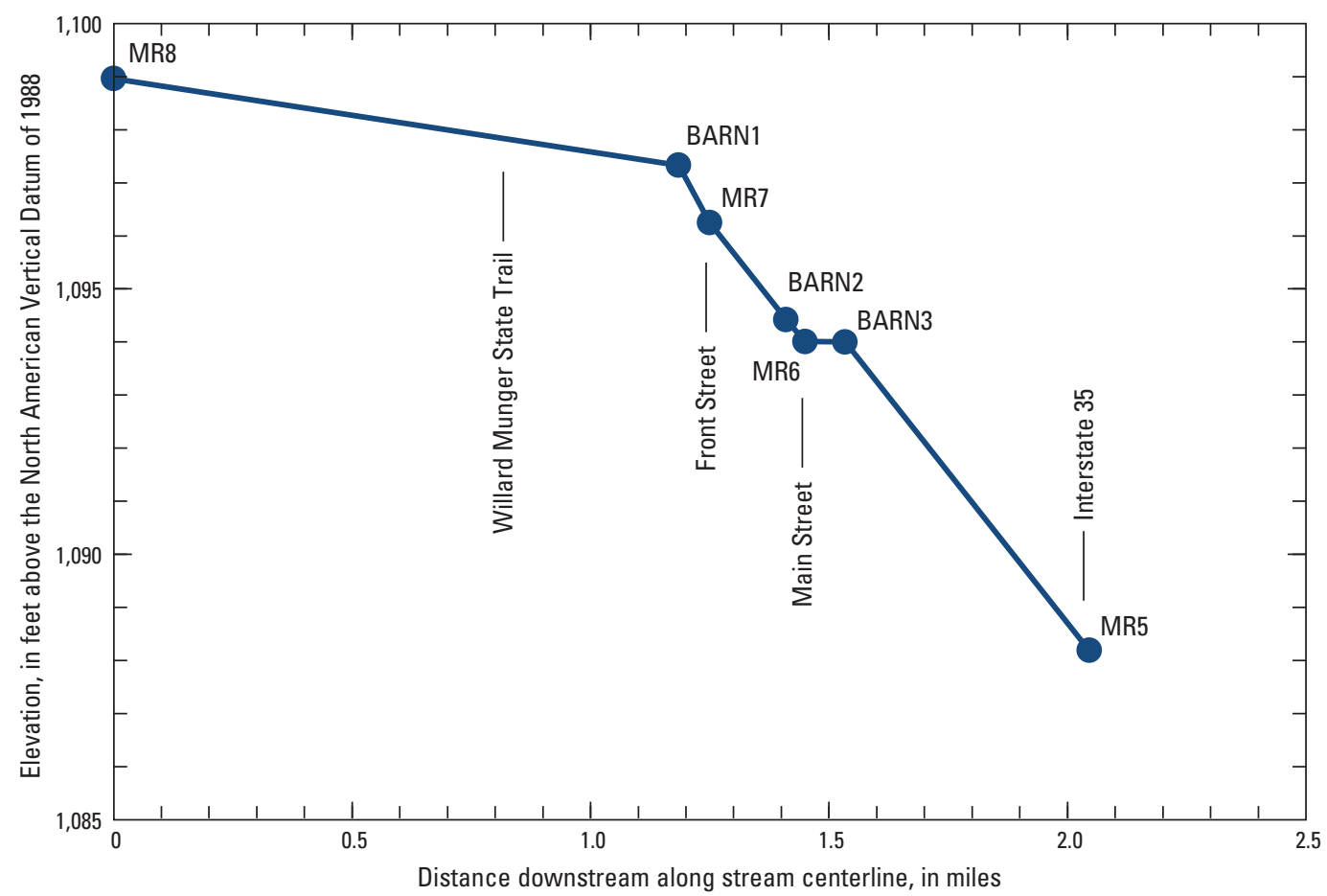

Figure 3-1. Flood-peak water-surface profile with selected high-water marks for the Moose Horn River at Barnum, Minnesota, for the flood of June 2012.

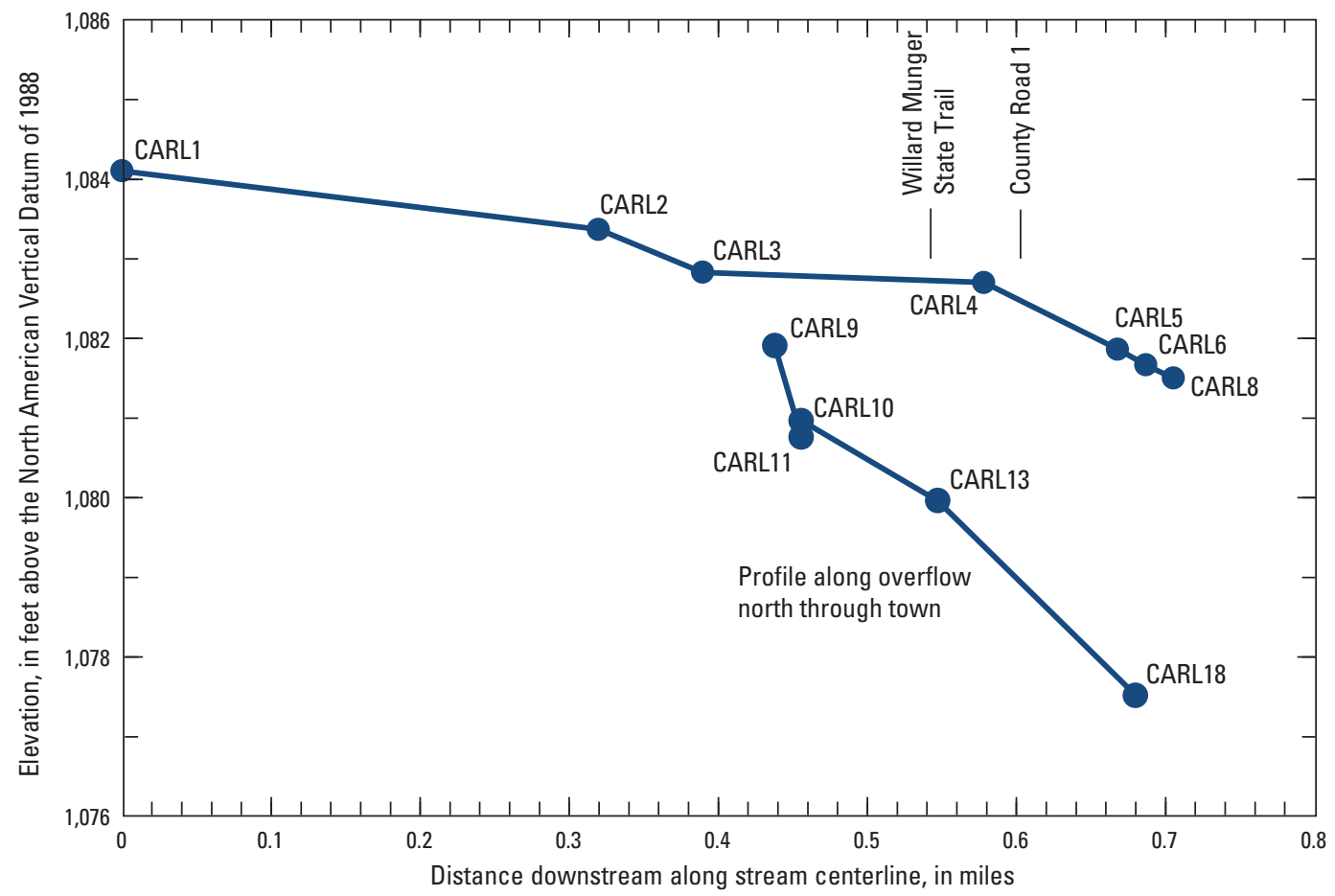

Figure 3-2. Flood-peak water-surface profile with selected high-water marks for Otter Creek at Carlton, Minnesota, for the flood of June 2012. 


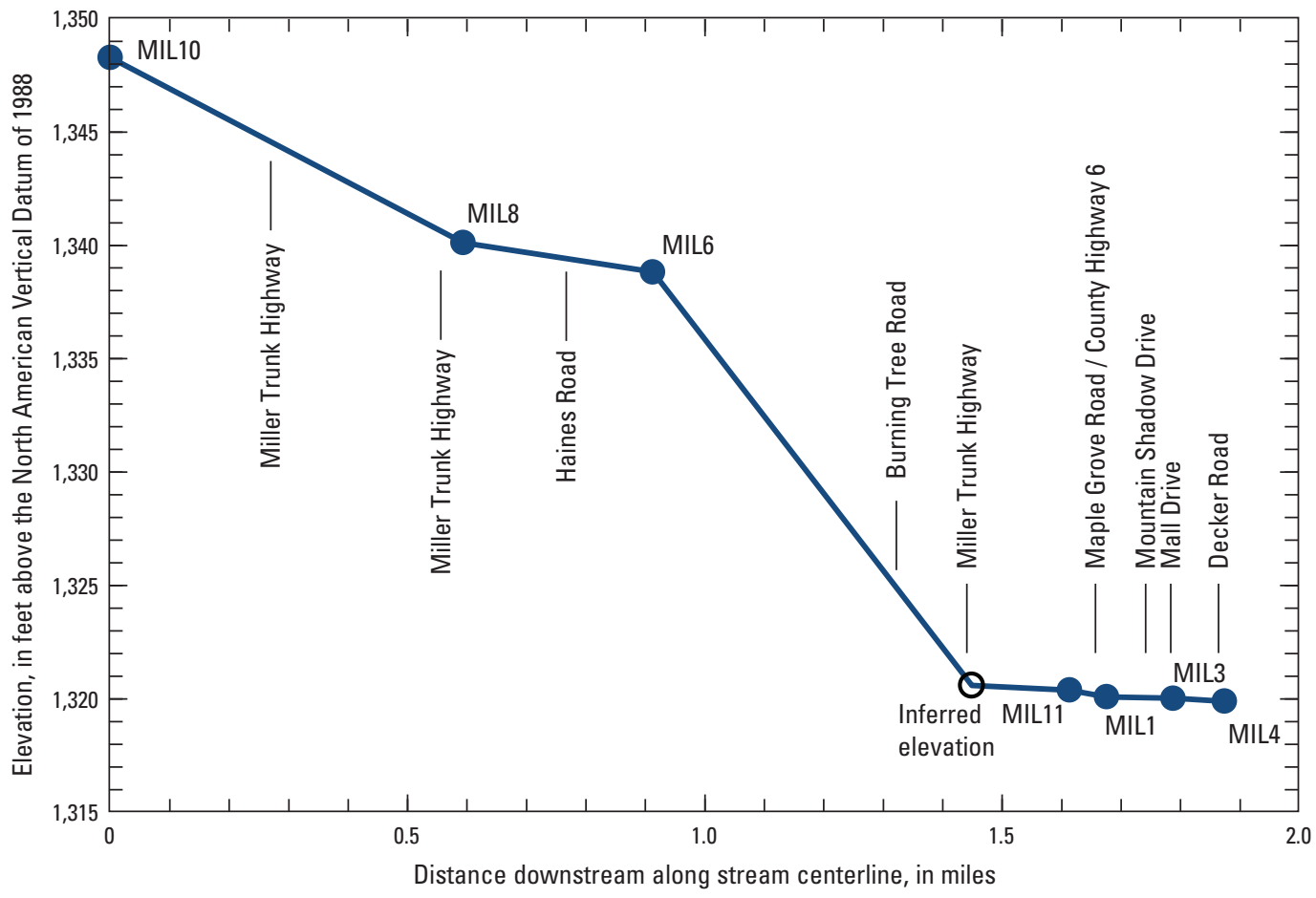

Figure 3-3. Flood-peak water-surface profile with selected high-water marks for Miller Creek at the Duluth Heights neighborhood, Duluth, Minnesota, for the flood of June 2012.

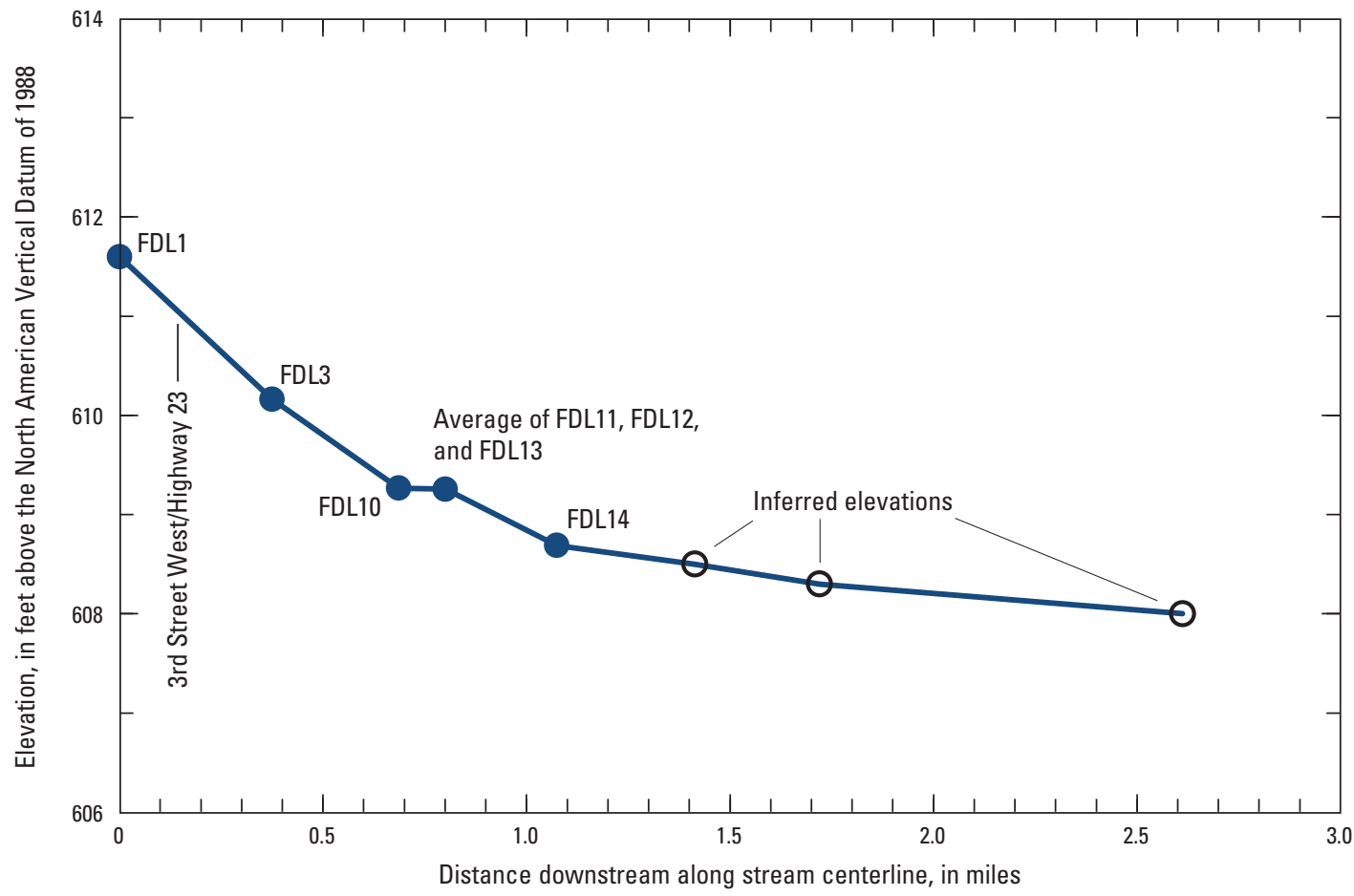

Figure 3-4. Flood-peak water-surface profile with selected high-water marks for the St. Louis River at the Fond du Lac neighborhood, Duluth, Minnesota, for the flood of June 2012. 


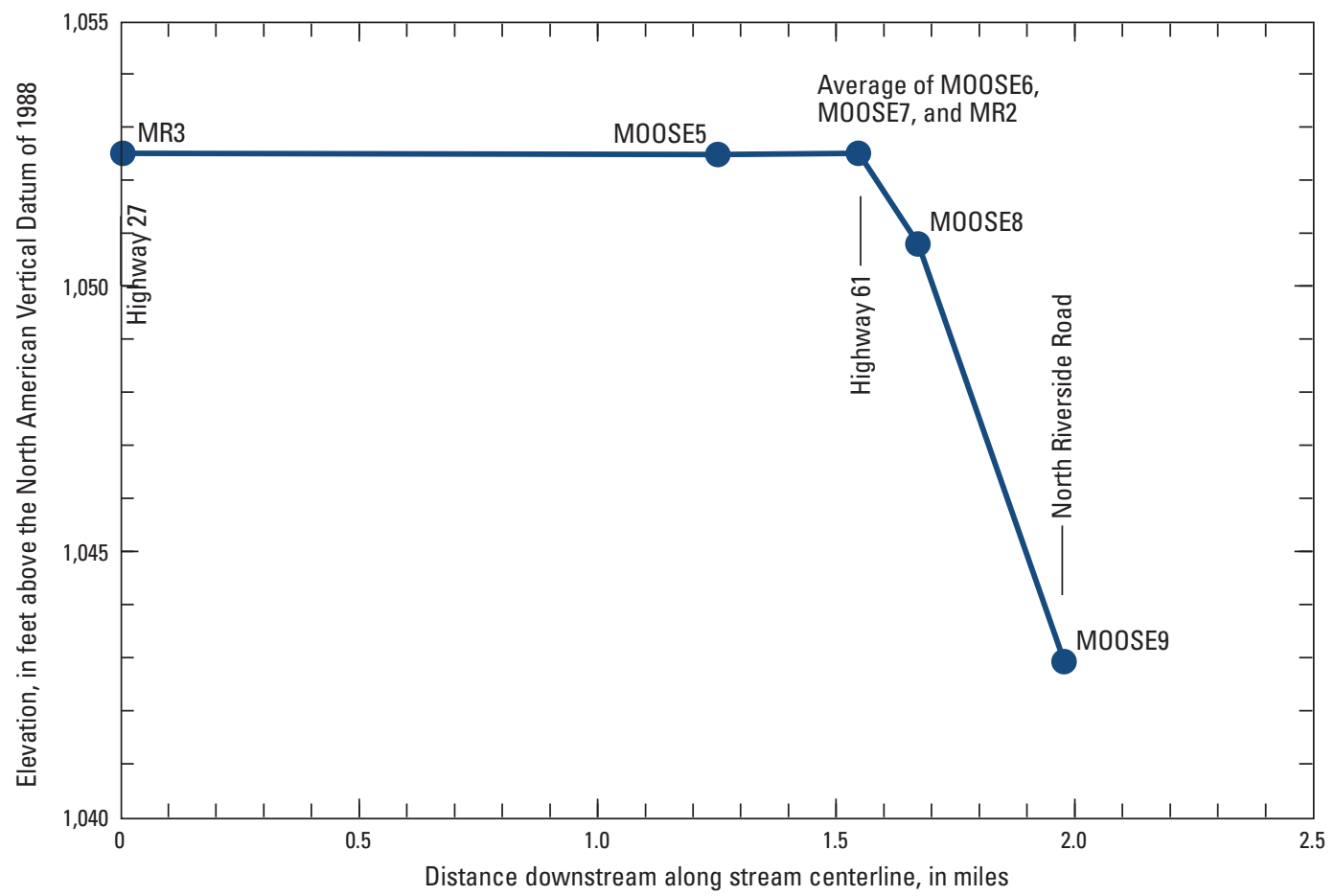

Figure 3-5. Flood-peak water-surface profile with selected high-water marks for the Moose Horn River and Moosehead Lake at Moose Lake, Minnesota, for the flood of June 2012.

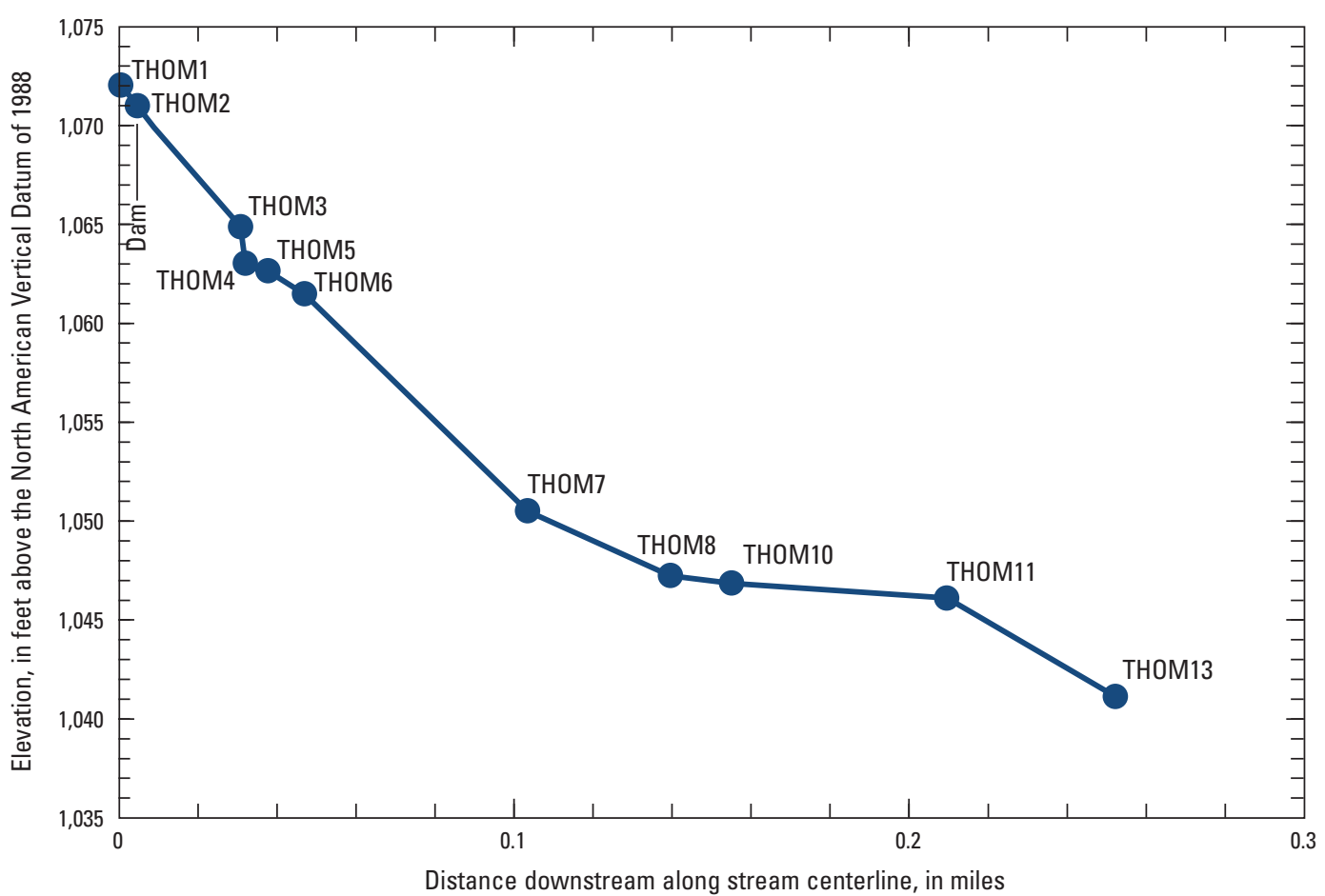

Figure 3-6. Flood-peak water-surface profile with selected high-water marks for the Thomson Reservoir outflow near the St. Louis River at Thomson, Minnesota, for the flood of June 2012. 
Publishing support provided by: Rolla Publishing Service Center

For more information concerning this publication, contact: Director, USGS Minnesota Water Science Center 2280 Woodale Drive

Mounds View, Minnesota 55112

(763) 783-3100

Or visit the Minnesota Water Science Center Web site at: http://mn.water.usgs.gov/ 
